\title{
WESTERN FRONTIER OR FEUDAL SOCIETY?: METAPHORS AND PERCEPTIONS OF CYBERSPACE
}

\author{
By Alfred C. Yen ${ }^{\dagger}$
}

\begin{abstract}
This Article examines how metaphors influence perceptions of cyberspace. Among other things, the Article studies the comparison of cyberspace to the American western frontier and the metaphor's construction of cyberspace as a "place" whose natural characteristics guarantee freedom and opportunity. This supports an often-made claim that cyberspace is different from real space, and that government should generally refrain from regulating the Internet.

The Article surveys the basis of the Western Frontier metaphor in academic history and popular culture, and concludes that the metaphor misleads people to overestimate cyberspace's "natural" ability to guarantee freedom and opportunity. The Article accomplishes this, in part, by offering feudal society as a metaphor for cyberspace and showing how prominent features of cyberspace correspond to key components of feudal society. The Article does not claim that cyberspace is thoroughly feudal, but it does argue that the feudal society metaphor valuably dislodges the Western Frontier metaphor and reminds us that law has an important role to play in shaping the future of the Internet.
\end{abstract}

\section{TABLE OF CONTENTS}

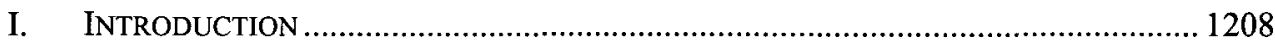

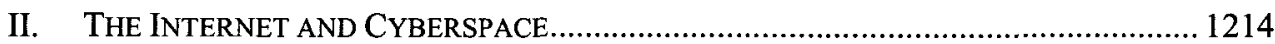

III. COMPARING CYBERSPACE TO THE WESTERN FRONTIER .................................... 1216

A. The Frontier Thesis and American Popular Culture ................................. 1216

(C) 2002 Alfred C. Yen

$\dagger$ Professor of Law, Boston College Law School. The author would like to thank the faculties of Boston College Law School, Boston University Law School, Hastings Law School, and the University of Houston Law School for valuable feedback given during faculty colloquia. Individual thanks are also owed to Keith Aoki, Wendy Gordon, Jeremy Paul, Justin Hughes, Jerry Kang, Joe Liu, Michael Madison, Mike Meurer, Maureen O'Rourke, Mary Bilder, Avi Soifer, and Dan Coquillette for their thoughtful ideas and comments. Sheila Bautista, Pauline Christo, Zachary Heiden, Jerry Marr, Sophia Sasaki, Dan Scales, and Jeff Strom provided able and helpful research assistance. Finally, the author would like to thank Mr. and Mrs. Darald and Juliet Libby for their generous financial support through the Boston College Law School summer faculty development program. 
B. Cyberspace and the Western Frontier.

C. The Western Frontier Metaphor and Legal Regulation of the Internet

D. Evaluating the Western Frontier Metaphor

IV. CYBERSPACE AND FEUdAL SOCIETY

A. Feudal Society

B. Internet Governance

C. The Feudal Character of Cyberspace

1. The Fragmentation and Privatization of State Power........................ 1239

2. The Development of Cybermanors..................................................... 1243

V. THE EFFECT OF THE FEUDAL SOCIETY METAPHOR............................................... 1248

A. User Exit and Emerging Feudal Practices ............................................... 1250

B. Contracts of Adhesion and Emerging Feudal Practices ............................ 1254

C. Intellectual Property and Emerging Feudal Practices.............................. 1256

1. The DMCA and Creation of Private Judiciaries ................................ 1257

2. Intellectual Property Cases and the Control of Cyberserfs ................ 1259

VI. CONCLUSION

\section{INTRODUCTION}

This Article offers feudal society as a metaphor for the emerging social organization of the Internet. It does so to illustrate how metaphors shape thinking about the Internet and to challenge the sometimes misleading comparison of the Internet to the Western Frontier.

1. Examples from academic legal writing include STUART BIEGEL, BEYOND OUR Control? CONFronting the LIMITS OF OUR LEGAL SYSTEM IN THE AGE OF CYBERSPACE 4, 13-18 (2001) (discussing use of "Wild West" metaphor); Mary Elizabeth Fitzgibbons, Foreword to the Fall 1999 Issue, 4-Fall J. TECH. L. \& POL'Y 0, at *2 (1999) ("Cyberspace has often been compared with the 'Wild West' of America's frontier days. This is an apt metaphor."), available at http://journal.law.ufl.edu/ techlaw/43/Foreword.html; Llewellyn Joseph Gibbons, No Regulation, Government Regulation, or Self-Regulation: Social Enforcement or Social Contracting for Governance in Cyberspace, 6 CORNELL J.L. \& PUB. POL'Y 475, 475 (1997) ("CCyberians' are present at the creation of the jurisdiction of cyberspace and at the closing of the electronic frontier."); Raymond Ku, Foreword: A Brave New Cyberworld?, 22 T. JEFFERSON L. REV. 125, $125-$ 26 (2000) (discussing connections among cyberspace, the electronic frontier, and the Western frontier); Shamoil Shipchandler, Note, The Wild Wild Web: Nonregulation as the Answer to the Regulatory Question, 33 CORNELL INT'L L.J. 435, 436 (2000) ("Today's Wild West is the Internet."); David Yan, Virtual Reality: Can We Ride Trademark Law to Surf Cyberspace?, 10 FORDHAM INTELL. PROP. MEDIA \& ENT. L.J. 773, 777 (2000) ("Originally, however, cyberspace was like the Wild West.").

Examples from general commentators include Andrew P. Morriss, The Wild West Meets Cyberspace, The FreEMAN, vol. 48, No. 7 (July 1998); Paul Ashdown, From Wild West To Wild Web: Public Intellectuals \& the Cyberspace Frontier, EXECUTIVE SpEeCHES, vol. 15, No. 2, 699 (2000); John Perry Barlow, Jack In, Young Pioneer!, Keynote Essay for the 1994 Computerworld College Edition, ๆी 6-7, available at http://www.eff.org/Infra/virtual_frontier_barlow_eff.article (Aug. 11, 1994) [hereinafter Barlow, Jack In] (urging young people to connect to the Internet as one might have urged 
The application of metaphor to the Internet is entirely sensible. It is an unavoidable and useful human habit to compare unfamiliar objects to familiar ones. People use apt metaphors because they stimulate the imagination, drawing attention to patterns and possibilities that would otherwise have escaped attention. If perceptions stimulated by metaphor become sufficiently ingrained, people may adopt them as reality and make them the basis for future beliefs and actions. At the same time, however, it is important to separate the application of metaphor from the complete apprehension of reality. Metaphors work because they provide perspective, but the adoption of one perspective necessarily omits insights offered by other perspectives. Accordingly, insight gets lost when one metaphor assumes enough prominence to crowd other ones out, especially if the prominent metaphor has misleading qualities. It therefore makes sense to develop and use a balanced set of metaphors when studying any object. ${ }^{2}$

a young person to go West); Mitchell Kapor \& John Perry Barlow, Across the Electronic Frontier, Electronic Frontier Foundation, I 4, available at http://www.eff.org/ Publications/John_Perry_Barlow/HTML/eff.html (July 10, 1990) ("Cyberspace is a frontier region"); John V. Lombardi, Killer Applications, the Net, and the Wild, Wild, West, Address at the Florida Government Technology Conference, I 6, available at http://jvlone.com/cyber2.html (Oct. 10, 1995).

Examples from the press include Internet Surfing Can Cut Into 'People Time', UPI, Feb. 16, 2000, ๆT 11-14 (comparing Internet to unsettled Western frontier), available at LEXIS, Nexis library, UPI file; Stephen Pounds, MCI Chairman Sees Internet as 'The Wild West', PALM BEACH Post, Apr. 30, 1995, at 3E; Lawrence J. Siskind, Settling the Wild Cyber Frontier: Domain Names Should be Treated as Property, TEX. LAw., Nov. 22, 1999, at 43 ("Across the vast expanse of cyberspace, wildcatters are at work, staking claims over thousands of domain names, hoping to strike it rich with one or more."); Mark Trumbull, Taming the 'Wild West' of the Global Internet, CHRISTIAN SCI. MONITOR, Nov. 14, 1995, at 12; Dawn Wilensky, The Internet, the Next Retailing Frontier, DisCOUNT StORE News, Dec. 4, 1995, at 6.

2. See Milner S. Ball, Lying Down Together: Law, Metaphor, and TheolOGY 22 (1985) (describing the importance of metaphor in shaping reality, the power of "preemptive metaphors," and the need for "access to alternate metaphors"); Clay Calvert, Comment, Regulating Cyberspace: Metaphor, Rhetoric, Reality, and the Framing of Legal Options, 20 HaSTINGS COMM. \& ENT. L.J. 541, 542-43, 547-49 (1998) (describing the use of the information superhighway metaphor for the Internet and its limitations); A. Michael Froomkin, The Metaphor is the Key: Cryptography, the Clipper Chip, and the Constitution, 143 U. PA. L. REV. 709, 718 (1995) ("As more and more settlers arrive in cyberspace, the nature of this new landscape will depend critically on the legal metaphors that the colonists choose to bring with them."); Dan Hunter, Cyberspace as Place, and the Tragedy of the Digital Anticommons, 91 CAL. L. REV. (forthcoming March 2003) (discussing the "cyberspace as place" metaphor and, in general, the widespread use of metaphors); Bruce P. Keller, The Game's the Same: Why Gambling in Cyberspace Violates Federal Law, 108 YALE L.J. 1569, 1571 (1999) (criticizing those who take the metaphor of cyberspace as an actual, separate place too literally); F. Gregory Lastowka, 
Not surprisingly, metaphors shape the perception of Internet reality. Of the many metaphors that have been applied to the Internet, ${ }^{3}$ the most prominent and influential has been the imagination of the Internet as a separate, new physical place known as "cyberspace" and its comparison to America's Western Frontier. This "Western Frontier" metaphor is both powerful and persistent, ${ }^{4}$ particularly in the United States. ${ }^{5}$ Americans

Note, Search Engines, HTML, and Trademarks: What's the Meta For?, 86 VA. L. REV. 835, 854-58 (2000) (noting influence and importance of metaphors); Michael J. Madison, Rights of Access and the Shape of the Internet, 44 B.C. L. REV. (forthcoming May 2003) (advocating the development of metaphors connected to experience); Maureen A. O'Rourke, Property Rights and Competition on the Internet: In Search of an Appropriate Analogy, 16 BERKELEY TECH. L.J. 561 (2001) (analyzing effect of analogies and metaphors on property rights and competition policy for the Internet); Jonathan J. Rusch, $C y$ berspace and the "Devil's Hatband", 24 SEATTLE U. L. REV. 577, 578-81 (2000) (noting the persistence of the Western Frontier metaphor and advocating the intelligent selection of metaphors based on the Western frontier); Timothy Wu, Application Centered Internet Analysis, 85 VA. L. REV. 1163 (1999) (criticizing tendency of various commentators who allow a single analogy to dominate their analyses of the Internet).

3. See EDIAS Software Int'l, LLC v. BASIS Int'l, Ltd., 947 F. Supp. 413, 419 (D. Ariz. 1996) (noting metaphors that compare the Internet to highways, shopping malls, and telephone systems); Jon. M. Garon, Media \& Monopoly in the Information Age: Slowing the Convergence at the Marketplace of Ideas, 7 CARDOZO ARTS \& ENT. L.J. 491, 589 (1999) (referring to a "portal metaphor" for the Internet); I. Trotter Hardy, Copyright Owners' Rights and Users' Privileges on the Internet: Computer RAM "Copies": A Hit or a Myth? Historical Perspectives on Caching as a Microcosm of Current Copyright Concerns, 22 DAYTON L. REV. 423, 436-37 (1997) (comparing the Internet to a cardiovascular system and a highway system); Andy Johnson-Laird, The Anatomy of the Internet Meets the Body of the Law, 22 DAYTON L. REV. 465, 469 (1997) (adding the metaphor of "global copying machine" to the "list of Internet metaphors"); Stephen McGeady, The Digital Reformation: Total Freedom, Risk, and Responsibility, 10 HARV. J.L. \& TECH. $137,139-41$ (1996) (referring to comparisons between the Internet and the Gutenberg printing press, and further using the Protestant reformation as a metaphor for the Internet); Tom W. Bell, Book Review, 28 J. MAR. L. \& CoM. 185, 186 (1997) (reviewing HENRY H. PERRITT, JR., LAW AND THE INFORMATION SUPERHIGHWAY (1996) (criticizing the information superhighway metaphor for the Internet as "outmoded" and comparing the Internet to the ocean).

4. See Rusch, supra note 4, at 577-79 (discussing the pervasive comparison of cyberspace to the Wild West); Lyrissa Barnett Lidsky, Silencing John Doe: Defamation \& Discourse in Cyberspace, 49 DUKE L.J. 855, 885 (2000) ("The Internet has often been compared to the Wild West, a frontier society free from the stifling conventions of civilization, and some have even argued that defamation law is an unnecessary anachronism in this new society."); Andrew P. Morriss, Miners, Vigilantes, \& Cattlemen: Overcoming Free Rider Problems in the Private Provision of Law, 33 LAND \& WATER L. REV. 581, 687 ("The 'Wild West' is a frequently applied metaphor for the Internet."); Steven Hetcher, Climbing the Walls of Your Electronic Cage, $98 \mathrm{MiCH}$. L. REV. 1916, 1916 (2000) (noting frequent comparison of cyberspace to an unexplored frontier with reference to the American West). 
imagine the Western Frontier as an unexplored place of abundant land, freedom, and opportunity. The West's remoteness ensured the absence of legal and social constraints associated with the civilized East. Those unhappy with Eastern constraints found freedom by moving west, where abundant land and resources ensured their prosperity.

One can see the Internet in a similar way. Cyberspace "pioneers" experience the Internet as a special place devoid of the rules and constraints of "real space." This makes cyberspace a place where people find freedom from real space rules. Additionally, many who have ventured into cyberspace have discovered that significant economic opportunities exist there. The Internet has become the electronic frontier from which freedom and prosperity will emerge.

Like all metaphors, the Western Frontier metaphor provides a particular perspective on the object described. The metaphor constructs the Internet as a version of the Western Frontier, a historical phenomenon that glorifies individuality and the benefits of minimal government. Put slightly differently, the Western Frontier metaphor suggests that the Internet will permit everyone to live a modern, improved version of America's westward expansion. Like the American West, the unregulated Internet has inherent characteristics that support unlimited economic opportunity, equality, individual freedom, and even political liberty. ${ }^{6}$ Private arrangements reached in cyberspace therefore have a particularly strong claim to legitimacy because the Internet makes people free and equal individuals who

5. This Article recognizes that the perspectives under discussion have a distinctly American orientation. This is hardly surprising, as the Internet originally developed under the auspices of the United States government. See infra notes 10-12 and accompanying text. Moreover, the Western Frontier metaphor operates by referring to a part of history dear to many Americans. Accordingly, the metaphor's effect is strongest on Americans, the very people who have had the largest influence over the Internet's development and operation. Cf. BIEGEL, supra note 1, at 125 ("[T]he culture of the Internet is predominantly American at this point in time."). Indeed, Justin Hughes, a professor at Cardozo Law School, suggested to the author that perceptions of the Internet would be very different if other countries had been primarily responsible for its development. Exploration of these possibilities would undoubtedly be interesting, but is beyond the scope of this Article.

6. See David G. Post, The "Unsettled Paradox": The Internet, the State, and the Consent of the Governed, 5 IND. J. GLOBAL LEGAL STUD. 521, 539 (1998) (arguing that the unregulated Internet naturally guarantees consent of the governed); David R. Johnson \& David G. Post, The New 'Civic Virtue' of the Internet, ๆ 7, in THE EMERGING INTERNET: THE 1998 REPORT OF THE INSTITUTE FOR INFORMATION STUDIES (The Aspen Institute ed., 1998), available at http://www.cli.org/paper4.htm; Internet Surfing Can Cut Into 'People Time', supra note 1, IT 11-14 (reporting idea that Internet's "endless frontier" expands social horizons). 
cannot exploit each other unfairly. These observations support the argument that society should accept the Internet and its developing social practices "as is," with minimal interference from government."

The use of the Western Frontier metaphor to support minimal Internet regulation is not, in and of itself, problematic. Minimal regulation could be a wise strategy for the Internet, and a metaphor that clarifies the relevant arguments helps. However, the Western Frontier metaphor's prominence crowds out other equally important perspectives. If society thinks of the Internet as a new Western Frontier, it will often refrain from using law to rectify problems in cyberspace because legal regulation does not fit com-

7. See infra Part III.C. Perhaps the most colorful statement of this view comes from John Perry Barlow's "Declaration of the Independence of Cyberspace," which reads:

Governments of the Industrial World, you weary giants of flesh and steel, I come from Cyberspace, the new home of the Mind. On behalf of the future, I ask you of the past to leave me alone. You are not welcome among us. You have no sovereignty where we gather.

We have no elected government, nor are we likely to have one, so I address you with no greater authority than that with which liberty itself always speaks. I declare the global social space we are building to be naturally independent of the tyrannies you seek to impose on us. You have no moral right to rule us nor do you possess any methods of enforcement we have true reason to fear.

Tी 1-2, available at http://www.eff.org/ barlow/Declaration-Final.html (Feb. 8, 1996). See also Paulina Borsook, CyBERSELFISH: A CRITICAL ROMP THROUGH THE TERRIBLY LIBERTARIAN CULTURE OF HIGH TECH 1-27 (2000) (describing the relationship between high tech culture and libertarian politics).

Professor Andrew P. Morriss offers a more developed version of this argument in his essay The Wild West Meets Cyberspace, supra note 1. Professor Morriss directly compares cyberspace to the Western frontier, noting that both are characterized by the general absence of state regulation. He goes on to tout the benefits of these laissez-faire conditions:

The nineteenth-century west was a place of almost limitless opportunity where, through market transactions and voluntary action, tens of thousands of strangers developed institutions that allowed them to take advantage of that opportunity in communities of peace and good order. Today we are only beginning the Information Rush. Like a forty-niner trying to imagine modern-day San Francisco while looking at the mud flats and tents of his day, we cannot foresee what forms the spontaneous order now evolving in cyberspace will take. What we can do is reject the use of the metaphor of "Wild West" as a justification for state intervention. Whether the demand is for enforcement authorities to restrict cryptography or antitrust regulators to crush competition, intervention will stifle freedom. If we are lucky, the Internet will turn out to be just like the American Wild West. 
fortably into the Western Frontier metaphor's romanticized tale of progress. This troubling use of the Western Frontier metaphor conveniently overlooks historical episodes of injustice and exploitation in the West ${ }^{8}$ that appropriate legal regulation might have prevented. We must therefore think of ways to challenge the Western Frontier metaphor's prominence so that alternate perspectives can emerge.

This Article elaborates on the foregoing observations and then offers feudal society as an alternate Internet metaphor. The metaphor may seem a bit odd because the Internet seems far removed from a society that flourished in Europe over 500 years ago. Nevertheless, this Article will show that prominent features of cyberspace map easily onto feudal society. ${ }^{9}$ This does not mean that cyberspace is thoroughly feudal, or that feudal society is the best or only metaphor to apply to the Internet. A feudal society perspective simply facilitates appreciation of the Internet in a way that the Western Frontier metaphor does not. The Feudal Society metaphor weakens the ideology of minimal Internet regulation by reminding us that government regulation played a significant role in dismantling undesirable aspects of feudal society. The claim is not that the Feudal Society metaphor is superior to the Western Frontier metaphor, or that a particular ideology of Internet regulation is necessarily correct. Instead, using both metaphors allows a richer appreciation of the Internet, its influence on society, and the possible role of law in regulating that influence.

The Article proceeds in five parts. Part II describes the Internet, its operation, and the perception of the Internet as a separate physical space. Part III analyzes the Western Frontier metaphor and its relationship to arguments in favor of minimal Internet regulation. It briefly explores flaws in the metaphor's account of Western Frontier history and concludes that the metaphor's influence should be countered by the development of new metaphors that highlight the things hidden by the Western Frontier image. Part IV presents feudal society as an alternate, equally plausible metaphor for the Internet. Part V considers some of the implications of applying the Feudal Society metaphor to the Internet, including the use of law to blunt emerging feudal practices in cyberspace. Part VI concludes by urging

8. See, e.g., DAVID HAWARD BAIN, EMPIRE EXPRESS: BUILDING THE FIRST TRANSCONTINENTAL RAILROAD 205-09 (1999) (describing the role that exploitative and racist employment practices played in building the transcontinental railroad); ROBERT M. UTLEY, HIGH NOON IN LINCOLN: VIOLENCE ON THE WESTERN FRONTIER (1987) (describing numerous acts of theft, fraud, exploitation, rape and murder perpetrated by individuals in Lincoln County, New Mexico during a late 19th century period of ineffective government).

9. See infra Part IV. 
more careful thought about legal regulation of the Internet and by offering some general ideas about the application of metaphors to the Internet.

\section{THE INTERNET AND CYBERSPACE}

Any discussion of the Internet as a "place" must first deal with the phenomenon of cyberspace. Cyberspace is the virtual space created by operation of the Internet, a network of computers that share information with each other. ${ }^{10}$ The Internet has its origins in a number of experimental networks created and operated with funding from the United States government. The earliest of these was a 1960s Department of Defense project called the "ARPANET." The ARPANET was eventually joined in the 1980s by the NSFNET, which was designed and operated by the National Science Foundation. ${ }^{12}$

Over time, these networks grew and developed into the modern Internet as private parties gained access to the network and the operation of the network passed to private, for-profit entities. ${ }^{13}$ Now, millions of people can connect to the Internet. ${ }^{14}$ This does not mean, however, that everyone connects to the Internet the same way. A relatively small number of large entities, like major corporations and the government, build and maintain the high-speed lines that form the Internet's backbone. ${ }^{15}$ They provide Internet access to themselves. By contrast, most entities and individuals gain access to the Internet from someone else, creating a hierarchy of computers. Operators of the Internet's backbone are at the top of the hierarchy. They then support a second level of computers by connecting them to the Internet. Those at the second level can then support a third, and so on. This hierarchy continues until no further delegation of Internet access occurs.

10. See BARRY M. LEINER ET AL., A BRIEF History of THE INTERNET, version 3.31, available at http://www.isoc.org/internet/history/brief.shtml (last revised Aug. 4, 2000). For more detail, see Jay P. Kesan \& Rajiv C. Shah, Fool Us Once Shame on You-Fool Us Twice Shame on Us: What We Can Learn from the Privatizations of the Internet Backbone Network and the Domain Name System, 79 WASH. U. L.Q. 89 (2001).

11. See Kesan \& Shah, supra note 10, at 101-03.

12. See id. at 103 .

13. See id. at 111-19.

14. A major impediment to genuine worldwide availability of Internet access is the lack of adequate wiring in the third world, particularly sub-Saharan Africa. See Hiawatha Bray, Africa Goes Online, Boston GloBE, July 22, 2001 at A1 (describing the lack of Internet access in Africa and measures being taken to remedy the problem), available at 2001 WL 3943399.

15. See Preston Gralla, How the InTERnet Works 5-7 (4th ed. 1998). 
Most private individuals connect to the Internet at the bottom of this hierarchy through Internet Service Providers, or "ISPs." The ISP generally provides a connection to the Internet, along with e-mail and other basic technology, in return for a fee. Information travels to and from the individual's computer through the ISP's computer, which in turn forwards that information up the hierarchy and on to the Internet. In short, the ISP acts as the individual's "gateway" to the Internet. ${ }^{16}$

The existence of cyberspace owes a good deal to the sheer number of individuals, businesses, and other entities now connected to the Internet. However, equal credit must go to the increased processing power of modern personal computers, faster transmission of data over the Internet, and specialized software that make it practical to send text, sound and image files over the Internet. Consider the possibilities now available to the typical Internet user. First, the multi-media capabilities of Internet browsers allow users to "surf" the Internet to view a virtually unlimited number of files that display text, images and sound. Hyperlinking means that a simple click of a button takes our user from files stored in one computer to those stored on another. Second, e-mail and real-time communication software allow Internet users to "chat" or otherwise communicate with each other interactively. ${ }^{17}$

Together, these technologies create the illusion that logging on to the Internet takes the user to the separate place of cyberspace. No one exists in cyberspace without an Internet account. However, once a person establishes an Internet account, she can visit cyberspace anytime she likes. Logging on gives her an apparently separate virtual life. In cyberspace, there are lots of "places" to "go." Cyberspace contains many inhabitants, some of whom will be "seen" only in cyberspace. ${ }^{18}$ She can make friends, fall in love, and buy goods and services for her "real space life" while living her virtual cyberspace life. She can even adopt a new identity. ${ }^{19}$ How-

16. See id. at 49-53.

17. For examples and descriptions of chat software see America Online, Inc., $A O L$ Instant Messenger, available at http://www.aim.com/index.adp (last visited Nov. 15, 2002); ICQ, Inc., What is ICQ?, available at http://www.icq.com/products/ whatisicq.html (last visited Nov. 15, 2002); and Microsoft, Inc., .NET Messenger Service, available at http://messenger.msn.com (last visited Nov. 15, 2002). For an example of video chat software, see Eyeball Networks Inc., Products, available at http://www.eye ball.com/products/index.html (last visited Nov. 15, 2002).

18. See Howard Rheingold, The Virtual Community: Homesteading on the ELECTRONIC FRONTIER 17-37, 176-88 (1993) (describing communications among people who had never met in "real space"), available at http://www.rheingold.com/vc/book.

19. See Brenda Danet, Text as Mask: Gender, Play, and Performance on the Internet, in CYBERSOCIETY 2.0: REVISITING COMPUTER-MEDIATED COMMUNICATION AND 
ever, all of this exists only as long as she is logged on to Internet. The act of turning off her computer removes her from cyberspace as surely as a flight from New York to Paris removes a traveler from the United States.

Of course, cyberspace is not a real place. Spatial terms such as "cyberspace," "web site," and "visiting" locations in cyberspace are all part of the metaphor commonly applied to the experience of sitting at a desk, logging on to the Internet, and viewing files sent by other Internet users. At first inspection, the maintenance of this fiction seems absurd. However, anyone who has spent significant time "surfing the 'net" understands the power of the cyberspace concept, and the numerous Internet identities different from the people who maintain them demonstrate that people believe in cyberspace as a separate place and live it every day. Even if the coldblooded realist rejects the whole thing as mass delusion, ${ }^{20}$ the fact remains that society talks about cyberspace as if it were real, and it is undeniably true that something of social significance is happening "out there." Accordingly, it is important to study the consequences of thinking about the Internet through metaphors that construct it as a special, separate place. ${ }^{21}$

\section{COMPARING CYBERSPACE TO THE WESTERN FRONTIER}

\section{A. The Frontier Thesis and American Popular Culture}

The Western Frontier metaphor is influential because it rests upon a serious intellectual thesis that popular culture has adopted, idealized and disseminated. This combination of serious history and popular culture has

COMMUNITY 129-158 (Steven G. Jones ed., 1998) (describing experimentation with gender identity on the Internet). This point was perhaps made most vividly in a cartoon that appeared in the New Yorker magazine in which one dog seated at a computer says to another, "On the Internet, nobody knows you're a dog." Peter Steiner, NEW YORKER, July 5, 1993, available at www.cartoonbank.com.

20. Interestingly, William Gibson, the science fiction author generally given credit for coining the term "cyberspace," described it as "a consensual hallucination." WILLIAM GIBSON, NEUROMANCER 51 (1st ed. Ace Books 1984).

21. See Madison, supra note 2 (identifying a rough consensus on the Internet as a place metaphor); Hunter, supra note 2 (identifying widespread adoption of the cyberspace as place metaphor and describing the importance of physical metaphors to human cognitive systems); Mark A. Lemley, Place and Cyberspace, 91 CAL. L. REV. (forthcoming March 2003) (identifying and analyzing use of the cyberspace as place metaphor). $C f$. Jonathan G. S. Koppell, No "There" There, ATLANTIC MONTHLY, Aug. 2000, at 16 (noting the influence and likely persistence of the term "cyberspace" and urging careful understanding of its consequences). 
created an enduring image of the Western Frontier whose shortcomings are difficult to diagnose and engage.

Frederick Jackson Turner first advanced the "frontier thesis" in 1893, thereby attributing the development of American society and American virtues to the Western Frontier. ${ }^{22}$ Turner wrote:

American social development has been continually beginning over again on the frontier. This perennial rebirth, this fluidity of American life, this expansion westward with its new opportunities, its continuous touch with the simplicity of primitive society, furnish the forces dominating the American character. The true point of view in the history of this nation is not the Atlantic coast, it is the Great West. ${ }^{23}$

According to Turner, the West's free availability of unsettled land created the economic opportunities and social values that made America great. Individuals without wealth could always move to the West to take advantage of its abundant wildlife and fertile soil. ${ }^{24}$ If a settler had sufficient initiative and persistence, prosperity would surely follow. ${ }^{25}$ Similarly, people who felt oppressed could liberate themselves in the West because its unsettled land was remote from the oppressive state and its legal regulations. ${ }^{26}$ There, in conditions close to the state of nature, people could discover on their own the uniquely American values that support human flourishing. ${ }^{27}$ Those values would, of course, include self-reliance, indi-

22. Frederick Jackson Turner, The Significance of the Frontier in American History, in REPORT OF THE AMERICAN HISTORICAL ASSOCIATION FOR 1893 199-227 (1894), reprinted in FREDERICK JACKSON TURNER, THE FRONTIER IN AMERICAN HISTORY 1-38 (1st ed. Henry Holt \& Co. 1920) [hereinafter TURNER, FRONTIER IN AMERICAN HISTORY].

23. TURNER, FRONTIER IN AMERICAN HISTORY, supra note 22, at 2-3.

24. Id. at 18 (claiming that availability of natural resources attracted settlers to the West).

25. Frederick Jackson Turner, The Problem of the West, Atlantic Monthly, Nov. 1896 [hereinafter TURNER, Problems of the West], reprinted in TURNER, FRONTIER IN AMERICAN HISTORY 212 ("The West was another name for opportunity. Here were mines to be seized, fertile valleys to be pre-empted, all the natural resources open to the shrewdest and the boldest.").

26. Frederick Jackson Turner, Contributions of the West to the American Democracy, ATLANTIC MONTHLY, Jan. 1903 [hereinafter TURNER, Contributions of the West], reprinted in TURNER, FRONTIER IN AMERICAN HISTORY 259 ("Whenever social conditions tended to crystallize in the east, whenever capital tended to press upon labor or political restraints to impede the freedom of the mass, there was this gate of escape to the free conditions of the frontier.").

27. According to Turner, the harshness of frontier living forced settlers to abandon the trappings of life governed by social convention and the state. Instead, settlers got back 
vidualism, equality, and a commitment to democracy. People of like mind could then find each other and create new settlements, towns, cities and states superior to the oppressive ones in the East. ${ }^{28}$

It would be remarkable if natural conditions guaranteed economic and social opportunity for even a brief period of any country's history. According to Turner's frontier thesis, the West provided these blessings to America from the time that Europeans arrived in North America to the settlement of the West Coast. The process of settling the Western Frontier, of finding economic opportunity and social progress in the bounty of free and unsettled land, became the defining feature of American society. Americans are American because they settled the West. ${ }^{29}$ American society progresses because regular contact with the Western wilderness implies a continual return to basic values, their reaffirmation, and the improvement of American democracy. America is a better place, and Americans are

to the basics - those things that were truly necessary to life. This allowed settlers to reinvent themselves in a distinctly American way:

In short, at the frontier the environment is at first too strong for the man. He must accept the conditions which it furnishes, or perish, and so he fits himself into the Indian clearings and follows the Indian trails. Little by little he transforms the wilderness, but the outcome is not the old Europe, not simply the development of Germanic germs, any more than the first phenomenon was a case of reversion to the Germanic mark. The fact is, that here is a new product that is American.

TURNER, THE FRONTIER IN AMERICAN HISTORY, supra note 22, at 4 . Turner further believed that the society built by Americans uniquely emphasized basic human virtues and avoided the superfluous trappings of European civilization. TURNER, Problems of the West, supra note 25, at 213 ("The United States is unique in the extent to which the individual has been given an open field, unchecked by restraints of an old social order, or of scientific administration of government.").

28. Turner's writing captures these thoughts with striking clarity:

Most important of all has been the fact that an area of free land has continually lain on the western border of the settled area of the United States. . . . These free lands promoted individualism, economic equality, the freedom to rise, democracy. Men would not accept inferior wages and a permanent position of social subordination when this promised land of freedom and equality was theirs for the taking. Who would rest content under oppressive legislative conditions when with a slight effort he might reach a land where in to become a co-worker in the building of free cities and free States on the lines of his own ideal?

TURNER, Contributions of the West, supra note 26, at 259. See also TURNER, Problems of the West, supra note 25, at 205-06 (describing continual rebirth of American society through interaction with the Western frontier).

29. See supra note 23 and accompanying text. 
even better people, ${ }^{30}$ because of the Western Frontier. Indeed, America must have a frontier to remain authentically American. ${ }^{31}$

The frontier thesis became one of the most influential ideas of the 20th century. During the period before World War I, most historians accepted the thesis as true. ${ }^{32}$ Even now, after considerable criticism from many corners, the thesis remains influential with historians ${ }^{33}$ and, perhaps more importantly, in popular culture. ${ }^{34}$ Many Westerns-both novels and movies-tell stories about Americans struggling to carve lives from untamed land, uncomplicated virtues, and the triumph of good individuals in the absence of the state. ${ }^{35}$ Indeed, the popularization of the frontier thesis is in large part responsible for its influence when applied to cyberspace.

30. Turner quotes an unnamed representative from western Virginia:

The Old Dominion has long been celebrated for producing great orators; the ablest metaphysicians in policy; men that can split hairs in all abstruse questions of political economy. But at home, or when they return from Congress, they have negroes to fan them asleep. But a Pennsylvania, a New York, an Ohio, or a western Virginia statesman, though far inferior in logic, metaphysics, and rhetoric to an old Virginia statesman, has this advantage, that when he returns home he takes off his coat and takes hold of the plow. This gives him bone and muscle, sir, and preserves his republican principles pure and uncontaminated.

TURNER, FRONTIER IN AMERICAN HISTORY, supra note 22, at 31.

31. Id. at 37-38 (reflecting on the disappearance of the Western frontier and predicting that American energy previously spent on the frontier will "continually demand a wider field for its exercise").

32. See Richard W. Etulain, Preface to Does The Frontier EXPerience MAKe AMERICA EXCEPTIONAL? at v (Richard W. Etulain ed., 1999) [hereinafter FRONTIER EXPERIENCE].

33. Id. (" $[\mathrm{N}] \mathrm{o}$ essay or book about American history attracts as much attention, pro and con, as Turner's essay ["The Significance of the Frontier in American History"].").

34. See Martin Ridge, The Life of an Idea: The Significance of Frederick Jackson Turner's Frontier Thesis, 40 MONTANA, THE MAG. OF W. HIST. 2 (1991), reprinted in FRONTIER EXPERIENCE, supra note 32, at 74. Ridge writes:

Turner's masterpiece, like Braque's cubist work-“Man with a Guitar"- has achieved a special place in American culture. It changed a vital part of the scholarly community, and its rhetoric has been absorbed into our everyday language. It changed the way most Americans continue to see themselves and their institutions. Moreover, it changed the way they are seen by others throughout the world. People who have never read "The Significance of the Frontier in American History" or heard of Frederick Jackson Turner-as is true of Braque and cubismidentify with it and recognize in it portions of a reality.

Id. at 84 .

35. See Michael T. Marsden, Savior in the Saddle: The Sagebrush Testament, in FOCUS ON THE WESTERN 93 (John G. Nachbar ed., 1974) (noting that the Turner argument "is acted out time and again as Western after Western unfolds on movie screens 
For example, consider Shane, a novel by Jack Schaefer that was made into a movie of the same title. ${ }^{36}$ The story is set in Wyoming of 1889. The reader learns that the novel's hero, Shane, is a gunman who divulges little of his past. ${ }^{37}$ Shane literally wears the marks of his hard life in the West, but that life has molded him into a man of uncommon physical strength and character. ${ }^{38}$ Shane possesses direct manners and virtues so obvious that, despite his gunfighter's demeanor, good people trust him. ${ }^{39}$

In an attempt to leave his gunfighting days behind, Shane becomes a helper at the small homestead farm of Joe and Marian Starrett. Joe's son, Bobby, worships Shane as a hero, as do Joe and Marian in their own way. ${ }^{40}$ At first, Shane's very presence seems to lighten the pressure the Starretts face from Fletcher, a cattle rancher bent on running the Starretts and 6 other homesteaders off the open range. ${ }^{41}$ Fletcher's ranching business and his apparent disregard of the homesteaders' legal claims establish a threat to the life and community that the good and decent homesteaders want to build.

Over time Fletcher's intimidation increases, but Shane-forged by the Wild West into the great individual of supreme moral virtue and physical strength - champions the homesteaders. Eventually, Fletcher hires a gun-

across this land"). See also JoHN G. CAWELTI, ThE SiX-Gun MystiQue (2nd ed. 1984) (analyzing the popularity and influence of the Western genre). For classic Western novels, see JAMES FENIMORE COOPER, THE PiONEERS (James D. Wallace ed., Oxford Univ. Press 1991) (1823); OWEN WISTER, THE VIRGINIAN (1902); ZANE GREY, RIDERS OF THE PURPLE SAGE (1912). For classic Western movies, see How the West was Won (Cinerama and Metro-Goldwyn-Mayer 1963); Shane (Paramount Pictures 1953).

36. JaCk Schaefer, Shane: THE CritiCal Edition (James C. Work ed., 1984) (1949) [hereinafter SHANE: CRITICAL EDITION] (Reprinting a restored version of Shane along with a selection of scholarly essays; all citations are to this edition). There are, of course, many distinguishable variations of the Western genre in both literature and film. See CAWELTI, supra note 35, at 113-19 (listing Western films by subject). At least one other writer has noted the significance of the Shane story to the comparison of cyberspace to the Western frontier. BIEGEL, supra note 1, at 14-15 (discussing the movie version of Shane).

37. SHANE: CRITICAL EDITION, supra note 36, at 77.

38. Id. at 62-63. Shane wears clothes made of fine material, but they are patched and stained. The material marks him as a person of status, but the patches and stains place his origin outside of civilization. Id. Later, the narrator's father tells his son that " $[\mathrm{t}]$ here's more right about [Shane] than most any man you're ever likely to meet." Id. at 129 .

39. Id. at 74-75.

40. From the outset, Marian is attracted to Shane. Their unrealizable affection for one another is portrayed as natural, indeed inevitable, because of Shane's superior qualities as a man. Even Joe recognizes that Shane is a better man than he. Id. at 203.

41. Id. at 133 ("The only shadow over our valley, the recurrent trouble between Fletcher and us homesteaders, seemed to have faded away."). 
man named Wilson to kill Joe because Joe is the homesteader with the grit to hold the others together. Shane, realizing that he cannot be a farmer, resumes gunfighting and kills Wilson and Fletcher in a showdown. Shane then rides out of town, leaving Joe to lead the homesteaders in the creation of homes and a prosperous community where young Bobby can grow up "strong and straight."

Shane presents a glorified, idealized version of Turner's frontier thesis. ${ }^{43}$ Shane's physical prowess includes gunfighting, a skill acquired only in the Wild West where the absence of the state forces individuals to protect themselves. Yet the Wild West has also made Shane uncommonly virtuous. The combination of physical and moral qualities taken from the West enables Shane to protect the homesteaders. Joe Starrett and his fellow homesteaders struggle to carve good lives from the Wild West. The land itself accepts their presence with great reluctance, as Joe discovers in his vain efforts to remove a large stump from his yard. ${ }^{44}$ Even the homesteaders' human antagonists represent a combination of human avarice and the Wild West. Fletcher's open range cattle business is one that could only have developed in the Wild West. Similarly, Wilson and his gunfighting skills exist only because of the Wild West. The absence of law enforcement removes the state from the equation, making self-reliance and individual initiative key factors in the story. In short, Shane is a tale of how the self-reliant initiative of a strong, virtuous person can overcome injustice and ensure the prosperity of an entire community.

The fusion of popular culture and the frontier thesis is highly significant. If only historians had considered the frontier thesis, it would have gained limited exposure and criticism would have blunted its force. As noted earlier, Turner's work expresses great optimism that a society forged in the West would be a great one devoid of imperfections associated with the Old World. ${ }^{45}$ However, many historians who came after

42. Id. at 263 .

43. See generally James C. Work, Settlement Waves and Coordinate Forces in Shane, 14 W. AM. LITERATURE 191 (1979), reprinted in SHANE: CRITICAL EDITION, supra note 36, at 307 (discussing Shane as a story about the interaction between different groups of settlers amid the backdrop of the Wild West).

44. SHANE: CRITICAL EDITION, supra note 36, at 82-84. Joe describes the stump to Shane: "That's the millstone round my neck. That's the one fool thing about this place I haven't licked yet. But I will. There's no wood ever grew can stand up to a man that's got the strength and the will to keep hammering at it." Id. The language quoted fairly rings with the notion that individual initiative is the characteristic needed to tame the West. It is also no coincidence that the stump gives way when Joe gets help from Shane, a man imbued with the raw power of the Wild West.

45. See supra notes $27-28$ and accompanying text. 
Turner have noted that he simply overlooked the American West's history of violence against indigenous peoples, racist sentiments against Mexican and Asian immigrants, subordination of women, and avaricious exploitation of the land. For them, Turner's thesis could not be right because the society predicted by Turner surely would have avoided these tragic mistakes. ${ }^{46}$ Accordingly, many academic historians now consider the Turner thesis a myth. ${ }^{47}$

By contrast, popular culture has romanticized the frontier thesis and practically guaranteed its public acceptance. Movies and novels reach many more people than academic writings do. Criticism generally directed at academic writing rarely interferes with the public's perception of the romanticized West presented in Western movies and novels. Stories about the natural qualities of the Western Frontier, the inherent virtues it instilled, and the inevitable triumph of good, self-reliant people are told over and over again to an accepting public, hungry for more. ${ }^{48}$ Popular culture capitalizes on the loss of the Western Frontier to create American nostalgia for the frontier's return. This nostalgia helps idealize the Western Frontier as a place where optimism should prevail because the very nature of the Western Frontier guarantees a good outcome. Frederick Jackson Turner could never have promoted his ideas this effectively. ${ }^{49}$

\section{B. Cyberspace and the Western Frontier}

Events of the 20th century and America's internalization of the frontier thesis have created conditions ripe for the application of the Western Fron-

46. See, e.g., Richard Hofstadter, The Progressive Historians: Turner, BEARD, PARRINGTON 103-06 (1968) (criticizing Turner for allowing patriotism to overwhelm his objectivity); DONALD WORSTER, UNDER WESTERN SKIES 7-13 (1992) (criticizing Turner for being uncritical and narrow in his perspective); HENRY NASH SMITH, VIRGIN LAND: THE AMERICAN WEST AS SYMBOL AND MYTH 250-60 (1950) (describing and criticizing Turner's thesis); John Mack Faragher, The Frontier Trail: Rethinking Turner and Reimagining the American West, 98 AM. HIST. REV. 106 (1993) (reviewing five works of "new Western history").

47. See WORSTER, supra note 46, at 12-18 (describing a "new Western history" that is "beyond myth" and setting forth its agenda of paying due regard to the voices of "invaded and subject peoples of the West," the economic drive behind a "ruthless assault on nature," and the role of power and hierarchy in the West).

48. Cf. CAWELTI, supra note 35, at 110-13 (presenting a three-page list of 106 major Western films from 1903 to 1969). Shane itself was retold many times. It first appeared as a serial in a magazine, then as a novel, then as a movie, and finally as a television series. Furthermore, its general plot outline has been recycled in the movie Pale Rider, starring American tough guy Clint Eastwood.

49. See BIEGEL, supra note 1 , at 12 ("It is generally agreed that the Wild West imagery of popular culture comes not from history books but from the Western film."). 
tier metaphor to the Internet. The upheavals of the twentieth century-two world wars, the Viet Nam experience, and the moral struggles of the civil rights movement- have contributed to a collective sense that America needs to revisit its fundamental values in order to chart its future course. Under the frontier thesis, such renewal would ordinarily occur in the wilderness of the Western Frontier, land that is now largely civilized. Even where significant tracts of land remain uninhabited, the state extends its reach, making it impossible for brave individuals to found new communities on values developed in the absence of the state.

Not surprisingly, Americans have been looking for a new frontier. Widely accepted national boundaries make the occupation of new lands impossible and rule out the possibility of actual land-based frontiers. Space and the ocean are candidates to be new frontiers, but so far the technical obstacles are too great. The Internet, however, appears to be just the ticket, and a number of American writers have promoted it that waynot just for America, but potentially the world. ${ }^{50}$ Cyberspace may be virtual space, but its characteristics resemble a romanticized Turnerian Western Frontier, where the state seems largely absent. ${ }^{51}$ This seeming absence makes cyberspace a dangerous wilderness characterized by free pornography, "spam," identity theft, rampant copyright infringement, gambling, and hacking. ${ }^{52}$ Its technological nature also makes cyberspace a difficult

50. As John V. Lombardi, former president of the University of Florida, has written: Cyberspace is the next frontier. Not space, not the undersea world, but cyberspace. Like the stylized world of the American wild West, cyberspace is a vast, unmeasured resource. Like the lands of the American frontier, it exists in an apparently trackless wilderness filled with unknown riches and opportunities, ungoverned and wild, available and unclaimed.

Lombardi, supra note 1, ๆ 6. Similarly, Paul Ashdown, a professor of journalism at the University of Tennessee, has noted:

The Western space became outer space as we turned our attention from Gunsmoke and Bonanza to Star Trek and Star Wars. Ronald Reagan brought us briefly back to the Frontier in the 1980s but by then we had discovered cyberspace which was even better than virtual Dodge City or The Final Frontier somewhere west of the Cosmos.

Ashdown, supra note 1. See also Morriss, supra note 1; Barlow, Jack In, supra note 1.

51. See Kapor \& Barlow, supra note 1, ๆ 6 (claiming that sovereignty over cyberspace is not well defined). See also supra notes 22-28 and accompanying text (describing the absence of the state from Turner's West).

52. See, e.g., Catharine A. MacKinnon, Vindication and Resistance: A Response to the Carnegie Mellon Study of Pornography in Cyberspace, 83 GEO. L.J. 1959 (1995) (noting free availability of pornography in cyberspace and arguing that such availability harms women); Dianne Plunkett Latham, Spam Remedies, 27 WM. Mitchell L. ReV. 1649 (2001) (describing undesired mass e-mails called "spam" and advocating legislation 
place to negotiate. Only computer-savvy settlers really know how to survive there. $^{53}$ At the same time, cyberspace contains abundant free land that bestows huge fortunes and social opportunities to those sufficiently brave and industrious to venture into its virtual wilderness. ${ }^{54}$ Founders of new "dot-coms," venture capitalists, and even ordinary investors participate in an Internet gold rush that has gone through a cycle of boom and bust. ${ }^{55}$ Others risk being stalked in order find love and friendship. ${ }^{56}$ For them, the

to restrict its use); Scot M. Graydon, Much Ado About Spam: Unsolicited Advertising, The Internet, and You, 32 ST. MARY's L.J. 77 (2000) (same); Kurt M. Saunders \& Bruce Zucker, Counteracting Identity Fraud in the Information Age: The Identity Theft and Assumption Deterrence Act, 8 CORNELL J.L. \& PUB. POL'Y 661 (1999) (exploring the problem of identity theft and the effect of legislation designed to combat the problem); Alfred C. Yen, Internet Service Provider Liability for Subscriber Copyright Infringement, Enterprise Liability, and the First Amendment, 88 GEO. L.J. 1833, 1834-35 (2000) (describing concern about copyright infringement on the Internet); Keller, supra note 2 (discussing gambling in cyberspace); Mary M. Calkins, They Shoot Trojan Horses, Don't They? An Economic Analysis of Anti-Hacking Regulatory Models, 89 GEO. L.J. 171 (2000) (describing and analyzing the problem of "hacking" as the unauthorized access of a computer).

53. In 1990, Mitch Kapor and John Perry Barlow, co-founders of the Electronic Frontier Foundation, wrote:

In its present condition, Cyberspace is a frontier region, populated by the few hardy technologists who can tolerate the austerity of its savage computer interfaces, incompatible communications protocols, proprietary barricades, cultural and legal ambiguities, and general lack of useful maps or metaphors.

Kapor \& Barlow, supra note 1 , ๆ 4. See also TURNER, FRONTIER IN AMERICAN HISTORY, supra note 27 (describing how settlers were forced to adapt to the harsh conditions of the West).

54. See Fitzgibbons, supra note 1 , at $* 2$ (characterizing cyberspace as a "land of opportunity"); Lastowka, supra note 2, at 855 ("Like the Old West, the Web combines a promise of territorial expansion and 'gold in the hills' with legends of a self-reliant and independent citizenry.").

55. See Janet Rae-Dupree, Executives Rush the Net: Top Managers Give Up the Corner Office to Seek Their Fortunes in the Wild Web, SAN JoSE MERCURY NEWS, Sept. 23, 1996, at 1E (reporting that executives are leaving traditional jobs for the Internet gold rush); Mike Allen, Internet Prospectors Pan for Business Opportunities, SAN DIEGo Bus. J., Dec. 6, 1999, at 17 (reporting comparison of frenzied purchase of Internet company stock to a gold rush); David Leonhardt, M.B.A. Boom Fades as Candidates Seek Instead the Rewards of the Internet, N.Y. TIMES, Nov. 28, 1999, §1 (Business/Financial Desk), at 40 (reporting on potential MBA students' "gold-rush mentality" about the Internet as seen by the Dean of the Dartmouth Tuck Business School). See also TURNER, Problems of the West, supra note 25 , at 212 (characterizing the West as "another name for opportunity" with abundant resources - including mines - available to "the shrewdest and boldest").

56. See Amy C. Radosevich, Thwarting the Stalker: Are Anti-Stalking Measures Keeping Pace with Today's Stalker?, 2000 U. ILL. L. REV. 1371 (describing use of the Internet to stalk victims); RHEINGOLD, supra note 18, at 17-27 (discussing formation of 
very technology that distributes pornography, pirated software, and junk email also unites them with others previously separated by physical geography. They are pioneers who found diverse new communities in the wilderness of cyberspace. ${ }^{57}$ Modern individuals who follow these Internet pioneers by logging on to the Internet therefore participate in the creation of a more prosperous and better society.

\section{The Western Frontier Metaphor and Legal Regulation of the Internet}

The Western Frontier metaphor provides an inspiring account of the Internet, but this account does not offer neutral truth beyond debate. Instead, the Western Frontier metaphor operates as propaganda supporting minimal regulation of the Internet. This becomes clear upon a brief review of arguments for and against such minimal regulation.

At one end of the debate, some of those favoring minimal regulation ${ }^{58}$ take the idea of cyberspace as a separate place so seriously that traditional government cannot effectively intrude. ${ }^{59}$ For them, the absence of conventional geographical borders in cyberspace removes territory as a justifica-

community and friends on the Internet). See also SHERRY TURKLE, LIFE ON THE SCREEN: IDENTITY IN THE AGE OF THE INTERNET (1995).

57. See John Markoff, Staking a Claim on The Virtual Frontier, N.Y. TIMES, Jan. 2, $1994, \S 4$ (Week in Review Desk), at 5 (referring to "hardy bands of pioneers who staked out the first electronic communities"); Richard Sullivan, All Fangled up in the Internet, DALlas MORNING NewS, May 11, 1994, at 11C (describing Internet pioneers who have already founded "frontier communities"). See also TURNER, Contributions of the West, supra note 26, at 259 (referring to the founding of "free cities and free States" in the West).

58. For examples of arguments favoring this position, see David R. Johnson \& David Post, Law and Borders-The Rise of Law in Cyberspace, 48 STAN. L. REV. 1367 (1996) [hereinafter Johnson \& Post, Law and Borders]; David G. Post \& David R. Johnson, "Chaos Prevailing on Every Continent": Towards A New Theory of Decentralized Decision-Making in Complex Systems, 73 CHI.-KENT L. REV. 1055 (1998) [hereinafter Post \& Johnson, Chaos Prevailing]; David G. Post, What Larry Doesn't Get: Code, Law and Liberty in Cyberspace, 52 STAN. L. REV. 1439 (2000); Gibbons, supra note 1; Dawn C. Nunziato, Exit, Voice, and Values on the Net, 15 BERKELEY TECH. L.J. 753 (2000) (reviewing LaWrence Lessig, CODE AND OTHER LAws OF CyBERSPACE (1999)); Shipchandler, supra note 1 . The most colorful statement of the libertarian position is John Perry Barlow's Declaration of the Independence of Cyberspace, supra note 7. See also BIEGEL, supra note 1, at 124 ("Commentators and in fact many companies continue to argue that self-regulation remains the most appropriate strategy ...”).

59. See Johnson \& Post, Law and Borders, supra note 58, at 1379 ("Treating Cyberspace as a separate 'space' to which distinct laws apply should come naturally."); Gibbons, supra note 1, at 477 ("Cyberspace is a community of 71 million individuals which has so far relied on a distinct culture of shared norms and common values to control their behavior."). 
tion for sovereign jurisdiction. ${ }^{60}$ Attempts by sovereign states to regulate the Internet must fail because the Internet's decentralized operation makes it impossible for any single state to control activity in cyberspace. This makes private ordering in cyberspace inevitable. ${ }^{61}$

More importantly, even if sovereign control of cyberspace could be established legally and practically, any such regime would be less desirable than private ordering because the Internet's inherent characteristics obviate the need for state regulation. In real space, state regulation is necessary because the physical limitations of real space force people to deal with those whom they would rather avoid. One cannot always choose or avoid one's neighbors, and sometimes it is just too much trouble to shop at a store distant from one's home, even if the distant store offers better prices and service. These circumstances sometimes give rise to disputes that could, in theory, be resolved privately. However, experience has shown that state intervention is appropriate and helpful because state power forces individuals to stop antisocial behavior that others cannot avoid. ${ }^{62}$

Cyberspace, however, does not suffer from the physical problems of real space. Individuals in cyberspace can visit an infinite number of people and places because everyone is simply a few mouse clicks away. Thus, state intervention is not required in cyberspace because the natural characteristics of cyberspace allow individuals to avoid or discipline undesirable behavior more effectively than they can in real space. Bothersome people create less trouble in cyberspace because it is easier to avoid particular web sites than malodorous litter on the lawn at next door. No Internet business can treat its customers poorly because cyberspace makes it easy for them to escape. A few clicks of the mouse allow them to leave for a different business that offers better treatment. ${ }^{63}$ Individuals will discipline those who behave inappropriately by moving, or threatening to move, within this virtual frontier, over time leading to an Internet free of undesirable behavior. In the strong version of this argument, this pattern of behavior creates a form of political utopia where all government takes place by

60. See Johnson \& Post, Law and Borders, supra note 58, at 1370-78.

61. See id. at 1372-73 (describing how sovereign attempts to regulate the Internet will fail); Gibbons, supra note 1, at 509 ("[T]he infrastructure of cyberspace is evolving too rapidly for governments to regulate efficiently.").

62. Cf. ROBERT NOZICK, ANARChY, STATE, AND UTOPIA ix (1974) ("Our main conclusions about the state are that a minimal state, limited to the narrow functions of protection against force, theft, fraud, enforcement of contracts, and so on, is justified ...").

63. See Johnson \& Post, Law and Borders, supra note 58, at 1398 (discussing ease of exit in cyberspace). See also Nunziato, supra note 58. For an interesting analysis of the Internet's facilitation of exit and its effect on the global economy, see Dan L. Burk, Virtual Exit in the Global Information Economy, 73 CHI.-KENT L. REV. 943 (1998). 
the explicit consent of the governed because all Internet users will be able to associate with privately created Internet sites that embody their preferred political values. ${ }^{64}$

On the other hand, those who favor more robust legal regulation of the Internet ${ }^{65}$ do not trust the "natural" characteristics of cyberspace to obviate the need for traditional government. They worry that an unregulated Internet could lead to the excessive concentration of power in private hands because the absence of regulation implies no restraint on the use of technology by the powerful for private advantage. ${ }^{66}$ They recognize the argument that the nature of cyberspace guarantees easy escape from oppression, but they doubt that the Internet works as advertised. ${ }^{67}$ Accordingly, they believe that the state appropriately intervenes to guide the Internet's development. ${ }^{68}$

A significant point of disagreement between the two sides of the debate is the claim that the "natural" characteristics of cyberspace blunt the dangers that could follow from the unregulated use of technology by powerful private parties. Awareness of this disagreement exposes the ideological operation of the Western Frontier metaphor. According to Turner, the Western Frontier ensured American freedom and prosperity precisely because resources were abundant and the state was absent. ${ }^{69}$ The Western Frontier metaphor constructs the Internet the same way. The minimally regulated Internet offers freedom and prosperity because cyberspace has a

64. See Johnson \& Post, Law and Borders, supra note 58, at 1398 (discussing how ease of movement in cyberspace leads to government by true consent).

65. See Lawrence Lessig, Code and Other Laws of Cyberspace (1999); ANDREW L. Shapiro, The Control Revolution: How the InTERnet is PutTing People IN Charge AND Changing The World We Know (1999); James Boyle, Foucault in Cyberspace: Surveillance, Sovereignty and Hardwired Censors, 66 U. CIN. L. REV. 177 (1997); Julie E. Cohen, Lochner in Cyberspace: The New Economic Orthodoxy of "Rights Management", 97 MiCH. L. REV. 462 (1998) (arguing against a laissez-faire policy towards the private contractual delineation of intellectual property rights); Jerry Kang, Cyber-Race, 113 HARV. L. REV. 1130 (2000); Keller, supra note 2 (advocating regulation of online gambling); Neil Weinstock Netanel, Cyberspace Self-Governance: A Skeptical View from Liberal Democratic Theory, 88 CAL. L. REV. 395 (2000); Paul M. Schwartz, Privacy and Democracy in Cyberspace, 52 VAND. L. REV. 1607 (1999) (advocating rules concerning privacy on the Internet).

66. See SHAPIRO, supra note 65 , at 25-52; Boyle, supra note 65 , at 196-201 (describing use of the Internet for surveillance and control); Schwartz, supra note 65 , at 1620-40 (describing use of technology to gather personal information).

67. See Netanel, supra note 65 , at $410-52$;

68. See LESSIG, supra note 65 , at 210-34; Netanel, supra note 65.

69. See supra notes $24-28$ and accompanying text. 
lot of "land" and very few state-imposed laws. ${ }^{70}$ In Turner's romanticized West, people who faced oppression could easily find freedom by moving further west. That freedom allowed self-sufficient individuals to succeed precisely because the absence of the state allowed them to create better lives and civic institutions on their own. ${ }^{71}$ Internet users who feel oppressed can do the same thing by clicking a mouse. ${ }^{72}$ In fact, an Internet user can find a place of his own more easily than a Western pioneer could because there are no physical distances to cross in cyberspace. Cyberspace is therefore an improved version of the American West where the state can only inhibit self-sufficient individuals from ensuring their own freedom and prosperity. Accordingly, it would be wise to apply minimal regulation to the Internet. ${ }^{73}$ Granted, this perspective would not necessarily rule out

70. See Johnson \& Post, Law and Borders, supra note 58, at 1395-96 (noting that it is easy for Internet users to create new "territory" in cyberspace by setting up new discussion groups); Morriss, supra note 1.

71. See supra notes $26-28$ and accompanying text.

72. See Nunziato, supra note 58 , at 753-54.

73. For laissez-faire arguments that draw support from the Western frontier, see Morriss, supra note 1 (arguing that the West provided opportunities because the government left it generally unregulated, and advocating a similar policy for the Internet); Post, supra note 6 , at 543 (claiming that the settlement of the New World led to a rethinking of sovereign power and arguing that cyberspace will have the same effect); Shipchandler, supra note 1 (comparing the Internet to the "Wild West" and using the comparison to argue against regulation of the Internet).

It is worth noting that many of these arguments also draw support from modern confidence in unregulated markets. Modern welfare economics operates on the premise that unregulated behavior under "perfect market conditions" automatically leads to a socially optimal allocation of resources. See ROBERT COOTER \& THOMAS ULEN, LAW AND ECONOMICS 38 (2d ed. 1997) (describing how general equilibrium under perfect conditions is socially optimal); HARVEY S. ROSEN, PUBLIC FinANCE 46 (4th ed. 1995) ("[A] competitive economy 'automatically' allocates resources efficiently, without any need for centralized direction ..."). Perfect market conditions include the absence of transaction costs, the complete absence of monopoly, costless access to all relevant information, and the complete internalization of costs and benefits. COOTER \& ULEN, supra, at 38-41 (identifying sources of market failure); ROSEN, supra, at 52-54. Unfortunately, perfect market conditions never exist. See ROSEN, supra, at 54. Government must therefore occasionally intervene in otherwise unregulated markets to correct problems raised by market imperfections, but only when the relevant imperfections are serious enough to block transactions that would otherwise have occurred under perfect conditions. See COOTER \& ULEN, supra, at 79-93 (describing how government can lower transaction costs); Guido Calabresi \& A. Douglas Melamed, Property Rules, Liability Rules, and Inalienability: One View of the Cathedral, 85 HARV. L. REV. 1089 (1972) (analyzing the use of property and liability rules in light of market imperfections); Alfred C. Yen, A Preliminary Economic Analysis of Napster: Internet Technology, Copyright Liability, and the Possibility of Coasean Bargaining, 26 U. DAYTON L. REV. 247, 258-60 (2001) (explaining market imperfection and occasional need for government intervention). Our society demonstrates 
all Internet regulation, but it does create a basic presumption against regulation beyond the recognition of basic property rights and the enforcement of $_{\text {contract. }}{ }^{74}$

\section{Evaluating the Western Frontier Metaphor}

An evaluation of the Western Frontier metaphor begins by recognizing how its influence pushes other perspectives from view. The value of this influence depends on whether the metaphor's lessons are well-considered.

its faith in unregulated markets by making the assumption that most market imperfections are not serious enough to warrant government intervention. We therefore leave most transactions unregulated despite the acknowledged existence of market imperfections.

It is possible to argue that the Internet brings society closer to perfect market conditions, and that government regulation of Internet is therefore relatively unnecessary. See Gibbons, supra note 1, at 529-30 (claiming that Internet technology reduces transaction costs); Post \& Johnson, Chaos Prevailing, supra note 58, at 1087-89 (arguing that low transaction costs of exit on the Internet increase the likelihood that low levels of government regulation will increase social welfare). While the Internet may improve markets, the Internet surely does not perfect them. Even if the Internet significantly lowers certain transaction costs, it still does not eliminate barriers to entry, ensure complete access to relevant information, internalize all externalities, or eliminate monopolies. Accordingly, economics can be used to support the libertarian position on Internet regulation, but the issue is far from settled. See Mark A. Lemley, The Law and Economics of Internet Norms, 73 CHI.-KENT L. REV. 1257 (1998) (providing a skeptical analysis of the claim that private ordering on the Internet will be efficient).

74. Indeed, Turner himself recognized the role of law in realizing the promise of the West. For example, the Homestead Act made western migration possible for many who otherwise would not have made the trip by guaranteeing settlers legal title to land they occupied. See FREDERICK JACKSON TURNER, Pioneer Ideals and the State University, Commencement Address at the University of Indiana (1910), in TURNER, FRONTIER IN AMERICAN HISTORY 276. However, he also believed that Americans influenced by the frontier could tolerate legal regulation only in limited amounts:

In brief, the defenses of the pioneer democrat began to shift from free land to legislation, from the ideal of individualism to the ideal of social control through regulation by law. He had no sympathy with a radical reconstruction of society by the revolution of socialism; even his alliances with the movement of organized labor, which paralleled that of organized capital in the East, were only half-hearted.

Id. at 277 . He also wrote:

Legislation is taking the place of the free lands as the means of preserving the ideal of democracy. But at the same time it is endangering the other pioneer ideal of creative and competitive individualism. Both were essential and constituted what was best in America's contribution to history and to progress. Both must be preserved if the nation would be true to its past, and would fulfil[1] its highest destiny.

Frederick Jackson Turner, The West and American Ideals, Commencement Address, University of Washington (June 17, 1914), in Wash. Hist. Q., Oct. 1914, reprinted in Turner, The Frontier in American History 307. 
If the metaphor rests on a reasonable account of history, its lessons gain credibility because that account offers a real example of how abundant land and the state's absence once led to the success of self-reliant individuals and the creation of a better society. It is at least plausible to claim that history will repeat itself in cyberspace. However, if the metaphor's account of history is inaccurate, then the metaphor misleads because it forecasts a quasi-utopian future in cyberspace on the basis of a history that never existed. The claim that the Internet's abundant "land" and minimal regulation will lead to a better society becomes a theory without historical antecedent. Indeed, there would be reason to believe that the Western Frontier metaphor hides a more accurate and complicated history of the West that society might not want to repeat in cyberspace. Society could then find itself unhappy with policies that are heavily influenced by the existing Western Frontier metaphor.

It is therefore instructive to note that the Western Frontier metaphor's history is, at best, incomplete. As stories like Shane make clear, the operating image of the Western Frontier metaphor is a one where the virtuous prevail and evil is wiped out. Unfortunately, the West was not such place. Genocide, racism, and personal exploitation in the name of progress comprise a significant portion of Western Frontier history, but popular culture has cemented a romanticized version of the West that ignores or discounts this reality. ${ }^{75}$

This makes the Western Frontier metaphor problematic because it encourages ignorance of the very real possibility that the Internet will foster undesirable social developments. Internalization of the Western Frontier metaphor creates the belief that minimal legal regulation "naturally" works well for the Internet, when effective legal regulation might have prevented the myriad social problems of the actual Western Frontier. ${ }^{76}$

75. See supra Part III.A.

76. The problem identified here is similar to the one analyzed by Professor Julie Cohen in her article Lochner in Cyberspace: The New Economic Orthodoxy of "Rights Management", supra note 65. In that article, Professor Cohen describes how "cybereconomists" have accepted as true a number of questionable premises about the economic efficiency of unregulated contracting and heavily defended property rights. Professor Cohen criticizes these premises as unconvincing, and describes how they function as "just-so stories" that make certain highly contestable policy choices-particularly a laissez-faire attitude towards the private delineation of intellectual property rights-seem natural and inevitable. See id. at 463-66.

The point being made by this Article is that our cultural acceptance of Turner's romanticized frontier thesis and its application to the Internet function the same way. We come to believe that the West really was the place where laissez-faire policies created a free and prosperous society when the truth of that claim is highly contestable. Once we 
This suggests that the Western Frontier metaphor could be improved by revising its history. If society's collective imagination could embrace the tragedies of the West as completely as its successes, the Western Frontier metaphor might give a fairly robust account of the potentials and pitfalls of cyberspace. However, these efforts alone will probably not be enough to correct the Western Frontier metaphor's misleading tug on Internet policy.

This difficulty arises because, as noted earlier, the history of the Western Frontier metaphor represents a fusion of popular culture and academic thought. Although academic criticism has already blunted the force of Turner's thesis among professional historians, ${ }^{77}$ Turner's rosy perspective persists in popular culture because popular culture does not pay attention to the criticism. Unlike serious historians, moviemakers can ignore the accusation that their movies do not accurately depict the West. They can claim, appropriately, that movies are fictional entertainment, and their success is measured not by fidelity to historical fact but instead by their popularity with audiences. They cannot help it if audiences prefer optimistic depictions of the West, nor can they be held responsible if audiences internalize fictional portrayals of the West as true. ${ }^{78}$

Perhaps more importantly, there is real doubt about whether peopleparticularly Americans - could successfully accept a chastened view of the Western Frontier even if popular culture began broadcasting one. ${ }^{79}$ Turner's frontier thesis swept the country in part because it offered an uplifting story that explained the existence and triumph of distinctly American virtues. That story has now become part and parcel of an American history that generally minimizes America's less admirable moments. It is, in fact, a central component of how Americans construct and identify themselves. A chastened view of the Western Frontier will always face

believe this, we are well down the road to constructing the Internet in the image of the romanticized West and applying laissez-faire regulatory policies to it.

77. See supra notes 46-47 and accompanying text.

78. Indeed, a moviemaker might claim that the primary consideration in producing any movie is economic profit, or ticket sales. People see movies to be entertained and feel good, so dark portrayals of the West would be financially risky. The possibility that we have literally been sold our rosy view of the West is a fascinating one that is beyond the scope of this Article.

79. Two movies that broadcast such a view were Dances with Wolves (Orion Pictures 1990), starring Kevin Costner, and Little Big Man (Paramount Pictures 1970), starring Dustin Hoffman. Despite their popularity and critical acclaim, neither movie has significantly changed the standard popular culture view of America's Western frontier. 
marginalization because its acceptance would challenge the very essence of American identity. ${ }^{80}$

The difficulties of reforming the Western Frontier metaphor suggest that the metaphor itself needs to be dislodged from its prominence. Continued application of the unreformed metaphor creates an incomplete and misleading influence on policy and crowds out other metaphors that offer alternate perspectives on the Internet. Minimal regulation of the Internet might then pass from one of many possible strategies to an unquestionable "truth" protected by an unchallenged Western Frontier ideology. We must therefore begin imagining the Internet from new perspectives that challenge the Western Frontier metaphor, and it is to this task that this Article now turns by offering feudal society as a metaphor for the Internet

\section{CYBERSPACE AND FEUDAL SOCIETY}

\section{A. Feudal Society}

In Europe, feudalism ${ }^{81}$ was a method of political and social organization that emerged from the natural and social conditions that prevailed during ninth and tenth century. ${ }^{82}$ Constant invasion and local feuds had

80. Historian Donald Worster has captured well the difficulties Americans have when contemplating the Western frontier:

Say the word "West" and, immediately, vistas of mustangs galloping across wide-open spaces under immense, unclouded skies fill our imaginations, and sober reason has to come panting after. Say the word and we are off living in a dream, experiencing its old powerful emotions but as ever finding it difficult to say how the dream ends. As a people, we are quick to invent fantasies but slower to find plausible, realistic endings for them.

WORSTER, supra note 46 , at 79.

81. Any definition of feudalism has its shortcomings. First, no two societies practiced feudalism in exactly the same way. Second, feudalism evolved over its three centuries as the dominant form of political and social organization in Europe. Accordingly, historians have found it difficult to agree on a precise definition of feudalism. See Elizabeth Brown, The Tyranny of a Construct: Feudalism and Historians of Medieval Europe, 79 AM. HIST. REV. 1063 (1974). Nevertheless, it is possible to give a general account of feudal societies and some of their most important characteristics.

82. For descriptions and analyses of feudalism, see MARC BLOCH, FEUDAL SOCIETY (L. A. Manyon trans., 1961); JosePh R. STRAYER, FEUDALISM (1965); F. L. GANSHOF, FEUdAlisM (Philip Grierson trans., 3rd Eng. ed. 1964); WALTER PhELPS Hall \& RoBERT GREENHALGH ALBION, A HiSTORY OF ENGLAND AND THE BRITISH EMPIRE (3d ed. 1953); Daniel R. CoQuillette, The Anglo-American Legal Heritage (1999); JoHN M. W. BEAN, THE DECLINE OF ENGLISH Feudalism 1215-1540 (1968); Richard J. Lazarus, Debunking Environmental Feudalism: Promoting the Individual through the Collective Pursuit of Environmental Quality, 77 IowA L. REV. 1739 (1992). 
created social chaos that exacted a great toll on both the land and the population. ${ }^{83}$ While order had to be restored, an individual monarch could not, as a practical matter, control large tracts of land by himself. Monarchs, therefore, had to find a way to delegate military and political responsibility to individuals who would remain loyal. Feudalism helped accomplish this.

The feudal state sprouted from a series of agreements between a king and his followers. The king, who claimed all of the country's land for himself, divided his land into parcels known as "fiefs" and granted them to his most loyal followers. In return, these "tenants-in-chief" ${ }^{, 44}$ swore their loyalty to the king and promised to provide military service, money, prayer, or civil service. ${ }^{85}$ The king and each tenant-in-chief formalized their roles as "lord" and "vassal" in a ceremony of homage, during which the lord would accept the vassal's pledge of fealty. ${ }^{86}$ Vassals who possessed fiefs could in turn subdivide their lands and become lords to vassals of their own. This process often continued through multiple layers of "mesne lords" who simultaneously acted as vassals to their superiors and lords to their inferiors. ${ }^{87}$ Over time, this hierarchical pattern of grants became sufficiently complex to permit some vassals to swear allegiance to more than one lord at a time, although theoretically each vassal had sworn supreme allegiance to one lord over the others. ${ }^{88}$

Feudalism worked by allowing kings to capitalize on the abundance of land, which was important to the creation of wealth in medieval times. ${ }^{89}$ Kings who granted fiefs did more than make their followers rich. They

83. See BLOCH, supra note 82 , at 3-39; GANSHOF, supra note 82 , at 3-4.

84. HALL \& ALBION, supra note 82 , at 66 (describing those who held fiefs directly from the king as "tenants-in-chief"); COQUILLETTE, supra note 82, at 96 (same).

85. HALl \& ALBION, supra note 82 , at $65-68$ (describing the Norman-French practice of feudalism); COQUILLETTE, supra note 82, at 95-97 (describing imposition of feudalism by William the Conqueror). The original obligation of service was military, but the practice of military service gradually deteriorated in favor of money because a lord's vassal would not necessarily be the best available warrior. Money payments were therefore preferred because they allowed the lord to establish his own private force of effective mercenaries. See STRAYER, supra note 82, at 51-53.

86. See GANSHOF, supra note 82, at 69-106 (describing various forms of vassalage, homage, and fealty); HALL \& ALBION, supra note 82, at 66-67 (describing homage and fealty).

87. COQUILLETTE, supra note 82, at 97; HALL \& ALBION, supra note 82, at 65-66.

88. See BLOCH, supra note 82 , at 211-28 (discussing multiple vassalage); HALL \& ALBION, supra note 82 , at 66-67 (noting that vassals might hold land from more than one lord).

89. See HALl \& Albion, supra note 82 , at 65 (referring to plentiful land held by European rulers). 
also ensured the loyalty of those to whom the king delegated the tasks of administering and defending the land. Possession of a fief entitled its holder to both occupy and exploit the land. Because their homes and prosperity depended on it, lords at every level of the system would administer and defend their lands to the best of their abilities. This close connection between an individual's private interest and his public responsibilities gave feudalism two of its most distinctive characteristics: the treatment of political authority as an incident of private property and the fragmentation of government.

First, the simultaneous transfer of private interests in land and political authority meant that private individuals often exercised significant amounts of state power as an incident of private property. Initially, lords did not always grant judicial, police and regulatory powers over fiefs and their inhabitants to vassals. ${ }^{90}$ Over time, however, such delegation became common as a matter of practical necessity. ${ }^{91}$ Individuals accumulated power as a result of their land holdings, and not as the result of appointment to public office. Even in those cases where the right to administer state functions remained separate from possession of a fief, lords often granted those powers to other followers, thereby increasing the treatment of state power as a private possession. ${ }^{92}$

Second, the subdivision and transfer of fiefs to inferior vassals led to the fragmentation of government. The association of land with the right and authority to govern meant that lords gave away some of their power whenever they granted land to their vassals. Over time, this practice took significant power from the king and his tenants-in-chief and vested it in local lords who often administered justice over their subjects with relative impunity. ${ }^{93}$

90. See GANSHOF, supra note 82 , at 156-67 (discussing varying degrees of unity between the granting of fiefs and the granting of political authority, police powers, and regulatory functions).

91. STRAYER, supra note 82 , at 36-42.

92. See GANSHOF, supra note 82 , at 157.

93. See STRAYER, supra note 82 , at 36-42 (describing fragmentation of government in feudal Europe and the practical independence of powerful lords); BLOCH, supra note 82, at 446 (listing fragmentation of authority as a key characteristic of European feudal society); GANSHOF, supra note 82 , at xv (noting that feudalism was marked by "a dispersal of political authority amongst a hierarchy of persons who exercise in their own interest powers normally attributed to the state and which are often, in fact, derived from its break-up"). 
While the above-described division of land and political authority provided the backbone of feudalism, ${ }^{94}$ it was not the only way in which land was allocated and exploited because the roles of lord and vassal existed only among those who occupied feudal society's higher circles. ${ }^{95}$ In order to recruit and maintain sources of labor necessary to make land productive, those holding fiefs relied on the manorial system. ${ }^{96}$ The foundation for the manorial system was the economic relationship between fief holders as "lords of the manor" and the peasants or "serfs" who lived on the lord's land. The relationship between lord and serf superficially resembled the one between lord and vassal. Like vassals, serfs received interests in land in exchange for service. However, the nature of the interest and service differed significantly from that of a vassal. A vassal held his fief as part of a relationship in which the king took an interest, while a serf held his interest as part of a relationship governed by the "custom of the manor."97 Additionally, a vassal owed his lord only specified services, while a serf frequently owed his lord open-ended services. ${ }^{98}$

The intensely local nature of the relationship between serf and lord meant that the lord could and did exploit the serf for the lord's profit. Service to the lord meant that a serf spent most of his time tilling the lord's fields. Even when the serf found time to work his own land, the lord still took a portion of the serf's production and forced the serf to pay fees for mandatory use of the lord's mill, oven, and other facilities. ${ }^{99}$ Moreover,

94. See Joseph R. Strayer, Medieval Statecraft and the Perspectives of HISTORY 63 (1971) ("Feudalism was a type of government in which political power was treated as a private possession and was divided among a large number of lords.").

95. HALl \& ALBION, supra note 82, at 66 ("The donor of the fief was always the lord, and the recipient the vassal; but every man involved in this relationship belonged to the upper classes."); BLOCH, supra note 82, at 241 (describing relations of dependence other than vassalage existing in lower portions of feudal society); COQUILLETTE, supra note 82 , at 98 (distinguishing free and unfree tenure).

96. See BLOCH, supra note 82 , at 241 (describing the manorial system as the dominant form of social organization for lower classes in feudal society and the importance of the manorial system in generating wealth for lords); HALL \& ALBION, supra note 82, at 69-70 (describing importance of the manorial system in generating wealth for upper classes of feudal society).

97. See BLOCH, supra note 82 , at 248 ("[T] he relations of the lord with the tenants were regulated only by 'the custom of the manor."); COQULLETTE, supra note 82 , at 98 (describing how the "unfree tenure" of serfs was protected only by the Lord of the Manor).

98. See COQuIlletTE, supra note 82, at 98 (describing how English serfs held land in return for "uncertain services").

99. See HALl \& AlBION, supra note 82, at 70-71 (describing the exploitation of serfs); BLOCH, supra note 82 , at 251 (describing the lord's monopolies); COQUILLETTE, supra note 82 , at 98 (describing the exploitation of serfs). 
serfs were "tied to the soil" and became the subjects of new lords if and when the manor changed hands. ${ }^{100}$ This exploitation had limits, however. Abused serfs could and did escape to neighboring manors whose lords offered better treatment. ${ }^{101}$ Even so, the life of a serf was one of exploitation and subjugation. Feudal society was clearly divided between its haves and have-nots. $^{102}$

\section{B. Internet Governance}

The development of the Feudal Society metaphor also requires a description of the Internet's governance. It is fashionable to say that no single entity could or should govern cyberspace because the Internet is too vast to submit to central authority. However, this statement is an exaggeration. While the Internet does have many users whose number and diversity sometimes render central control impracticable, some central coordination must exist so that computers attached to the Internet can share a common communications protocol. ${ }^{103}$ The Internet therefore has always required a person, entity, or group to make decisions about basic technology that all computers on the network must use. The first such decision-makers were the scientists and engineers who developed the Internet on behalf of the United States government. ${ }^{104}$ Over time, two private, nonprofit entities have taken over significant portions of this task and now provide limited oversight of Internet operations.

The first of these entities is the Internet Society ("ISOC"), a professional membership society whose members come from over 150 coun-

100. See HALL \& AlBION, supra note 82 , at 69 (noting that serfs were "tied to the soil.").

101. As Marc Bloch wrote:

Of course the lords sought to retain their peasants. What was the estate worth without labour to work it? But it was difficult to prevent desertions because, on the one hand, the fragmentation of authority was more than ever inimical to any effective police control and, on the other, the great abundance of virgin soil made it useless to threaten with confiscation a fugitive who was almost always certain of finding a new place for himself elsewhere.

Bloch, supra note 82, at 263. See also COQUILLETTE, supra note 82, at 98 ("'Good' lords kept their serfs, while cruel lords saw their serfs 'disappear' to the lands of better masters, who would carefully fail to report their presence.").

102. See HALl \& ALBION, supra note 82, at 69 ("The manorial relation, unlike the mutually advantageous political feudal relationship, was most unequal; for it gave almost everything to the lord and almost nothing to the peasant.").

103. See Gralla, supra note 15, at 2, 13 (describing how computers connected to the Internet communicate using the TCP/IP protocol suite).

104. See LEINER, ET AL., supra note 10. 
tries. ${ }^{105}$ Today, the Internet Architecture Board ("IAB"), an advisory committee within ISOC, makes decisions about the standard technical architecture deployed on the Internet. ${ }^{106}$ Although no sovereign's law mandates compliance with IAB standards, it would be impractical to connect a computer to the Internet without such compliance. The IAB's standards presently require implementation of a data communication protocol suite called TCP/IP (Transmission Control Protocol/Internet Protocol). ${ }^{107}$ Any person can therefore-at least in theory-connect her computer to the Internet as long as that computer implements TCP/IP. ${ }^{108}$

The second of these entities is The Internet Corporation for Assigned Names and Numbers ("ICANN"), a nonprofit corporation recognized by a number of governments to administer the so-called Domain Name System ("DNS"). ${ }^{109}$ ICANN oversees the process and systems ensuring that each domain name maps to the correct IP address. ${ }^{110}$ Information sent across the Internet finds its way to the proper computer because the receiving computer's IP address tells other computers where data packets should be sent. ${ }^{111}$ In theory, Internet users could rely solely on numerical IP addresses to send e-mail and view web sites. However, the bland characteristics of numerical strings make them hard to remember. Using the TCP/IP protocol suite with the DNS solves this problem by allowing users to identify specific computers with ordinary words. ICANN administers and coordinates the DNS ${ }^{112}$ by, among other things, maintaining servers that match domain names to fixed IP addresses, ${ }^{113}$ accrediting domain name

105. See id.

106. See Internet Architectural Board, IAB Overview, available at http://www.iab. org/overview.html (last modified Nov. 3, 2000).

107. See Gralla, supra note 15 , at 13 .

108. Similar decisions concerning the Internet application known as the World Wide Web are made by the World Wide Web Consortium ("W3C"), an organization comprised of 500 member organizations from around the world. See W3C, About the World Wide Web Consortium, available at http://www.w3.org/Consortium (last modified Nov. 16, 2002). The close relationship between the Internet and the World Wide Web means that those connecting to the Internet will likely also comply with technological specifications necessary to use the World Wide Web.

109. See ICANN, ICANN Fact Sheet, available at http://www.icann.org/general/fact sheet.htm (last updated Feb. 17, 2001).

110. See InterNIC, The Domain Name System: A Nontechnical Explanation-Why Universal Resolvability Is Important, available at http:/www.internic.net/faqs/ authoritative-dns.html (last updated Oct. 5, 2002) (discussing how IP addresses work with DNS).

111. Id.

112. See id. (describing the DNS and ICANN's administration of the DNS).

113. See ICANN, ICANN Fact Sheet, supra note 109 (setting forth ICANN's responsibilities). 
registrars, ${ }^{114}$ and approving the establishment of new regional registries who distribute IP addresses. ${ }^{115}$

The DNS operates by establishing a hierarchy of Internet domains. The Top Level Domains ("TLDs") include the familiar .com, .edu, .org, .net, and .gov, as well as newly created ones like .biz and info. ${ }^{116}$ Various entities (generally private corporations) operate each of these domains by keeping a list that matches every domain name within the domain to its corresponding IP address. For example, VeriSign Global Registry Services currently manages the .com domain. ${ }^{117}$ VeriSign owns and operates the computer that authoritatively matches the IP address corresponding to aol.com, the domain associated with America Online. Thus, when a user enters aol.com into her web browser, her computer sends a request to the computer operated by VeriSign for the IP address associated with aol.com. ${ }^{118}$ The VeriSign computer responds with the IP address, enabling the user's computer to communicate directly with the computer operated by America Online.

The TLDs occupy the uppermost level of the domain name hierarchy. Each TLD sits over other domains that govern domain names and IP addresses of their own. For example, a user accessing the University of Arizona James E. Rogers College of Law types "law.arizona.edu." This sends a request to Network Solutions, Inc., the operator of the TLD ".edu," which sits over the domain "arizona.edu" operated by the University of Arizona. Network Solutions effectively refers the user to the University of Arizona, which in turn operates a computer that matches an IP address with "law.arizona.edu." That computer will then give the IP address to the

114. See ICANN, Registrar Accreditation: Overview, available at http://www.icann. org/registrars/accreditation.htm (last updated June 19, 2001) (describing ICANN's accreditation of domain name registrars).

115. See ICANN, ICP-2: Criteria for Establishment of New Regional Internet Registries, available at http://www.icann.org/icp/icp-2.htm (last updated July 7, 2001) (setting forth ICANN's criteria for establishing new local Internet registries and describing their roles, including the allocation of IP addresses).

116. See Internet Assigned Numbers Authority, Generic Top-Level Domains, available at http://www.iana.org/gtld/gtld.htm (last updated Aug. 262002 ).

117. See Internet Assigned Numbers Authority, Domain Name Services, available at http://www.iana.org/domain-names.htm (last updated Nov. 7, 2002) (listing top level domains); Internet Assigned Numbers Authority, Generic Top-Level Domains, available at http://www.iana.org/gtld/gtld.htm (last updated Aug. 26, 2002) (listing existing and new top level domains and the registrars responsible for their operation).

118. As a technical matter, the request might also go to a different computer that simply copied information from the VeriSign computer. See InterNIC, supra note 110. 
user, who can then communicate with the computer operated by or on behalf of the law school. ${ }^{119}$

The standards set up by ISOC and ICANN govern the connection of computers to the Internet and, by extension, the methods by which a person establishes an Internet presence. A person who wants to set up an Internet presence needs to accomplish two things. First, she connects to the Internet using a computer that implements TCP/IP. If she is an ISP or other large user of Internet resources, she could accomplish this by providing her own high-speed lines to become part of the Internet's backbone. If she desires only residential service, however, she will likely purchase the necessary connection from someone else and connect to the Internet near the bottom of its hierarchy of computers.

Second, she obtains an IP address and has it mapped to a domain name that will allow Internet users to communicate with her computer. Once again, she can choose to enter at various points in the Internet's hierarchy. If she desires her own name such as "SallyLawyer.com," she can register it with VeriSign or a registrar who does business with VeriSign. If she is content with a lesser domain name such as "SallyLawyer.LesserDomain.com," she can register that name with the operator of the domain "LesserDomain.com." 220 Finally, she can simply "piggyback" on a computer that already has a domain name. This would result in a URL like "LesserDomain.com/SallyLawyer.html" or an e-mail address like "SallyLawyer@LesserDomain.com."121 Although all three of these methods are available to anyone who wants to use them, ordinary individuals generally use the latter method through a commercial ISP, while businesses and large institutions more frequently use one of the former methods.

\section{The Feudal Character of Cyberspace}

\section{The Fragmentation and Privatization of State Power}

The feudal character of cyberspace emerges from the hierarchical privatization of its government associated with the granting of Internet domains. In particular, ICANN is a private entity that controls a most precious commodity-cyberspace "land" in the form of domain names. ${ }^{122}$

119. See id.; Gralla, supra note 15 , at 18-19, 33.

120. See Gralla, supra note 15 , at 17.

121. See id. at 17, 169-71 (explaining e-mail addresses and URLs).

122. As a matter of theory, ISOC and ICANN function as technical standard setting bodies that merely facilitate coordination among various Internet users. This implies that ISOC and ICANN play only minor roles in larger questions of Internet policy. For example, ICANN's Fact Sheet states: 
Like a feudal king, ICANN grants "cyberfiefs" to those who promise to pay money and abide by ICANN's rules in exchange for Internet domains. ${ }^{123}$ Recipients of cyberfiefs need only comply with minimal technical standards such as TCP/IP before making their cyberfiefs operational. ICANN distributes these cyberfiefs in a manner reminiscent of the methods used by feudal kings. As noted earlier, ICANN divides the available "cyberland" into TLDs such as .com, .edu, and .org. It then delegates the management of TLDs to TLD managers like VeriSign Global Registry Services. TLD managers then deal with various Internet domain name registrars, who in turn deal with general public. ${ }^{124}$ This pattern of distribution makes TLD managers' status analogous to tenants-in-chief and domain name registrars' status analogous to mesne lords, and it effectively creates a class of "cyberlords" that includes TLD managers, registrars, ISPs, businesses, and others who obtain and exploit significant interests in "cyberland."

The hierarchical distribution of cyberfiefs means that, as in feudal society, every interest in cyberland is held from a superior computer operator who functions as lord over vassal or serf. This hierarchical distribution of cyberfiefs affects cyberspace in the same way that the granting of fiefs affected medieval Europe. State power becomes an incident of private property that gets fragmented through delegation to numerous private parties. This occurs because cyberlords generally delegate powers of government whenever they grant a cyberfief. Like feudal monarchs, they must do so because the Internet has become too unwieldy for any attempt to manage

As a technical coordinating body, ICANN's mandate is not to "run the Internet." Rather, it is to oversee the management of only those specific technical managerial and policy development tasks that require central coordination: the assignment of the Internet's unique name and number identifiers.

ICANN, ICANN Fact Sheet, supra note 109. In practice, however, the "technical" matters handled by ISOC and ICANN inevitably involve significant policy issues that push ISOC and ICANN towards the very role they disclaim. See Kesan \& Shah, supra note 10, at 169-91; Joseph P. Liu, Legitimacy and Authority in Internet Coordination: A Domain Name Case Study, 74 IND. L.J. 587 (1999) (demonstrating how ostensibly "technical" decisions about domain names actually involve value choices usually resolved by government institutions).

123. It currently costs $\$ 35$ to register a domain name in the .com TLD for one year. See VeriSign, Domain Name Registration Page, available at http://www.netsol.com/ en_US/name-it (last visited Nov. 16, 2002). Those who register domain names also agree to, among other things, ICANN's Uniform Domain Name Dispute Resolution Policy, at www.icann.org/dndr/udrp/policy.htm (last updated May 17, 2002) (governing disputes about ownership of domain names).

124. See supra notes $112-118$ and accompanying text. 
all aspects of its operation. New cyberlords therefore face very few restrictions on how they operate their computers. Cyberlords can post whatever content they like on their computers, permit or refuse communications from particular individuals and domains, limit the number of users their computers serve, or observe the behavior of users. ${ }^{125}$ The political nature of these powers becomes even clearer upon examination of the role that cyberlords play in the ability of individuals to enter and experience cyberspace.

Ordinary individuals generally get Internet access by purchasing service from a commercial Internet Service Provider ("ISP") or employers who act as ISPs. The typical ISP is a cyberlord who sells access to the Internet through a computer or computers for which he has registered one or more domain names. Such an ISP typically provides the individual with a connection for the user's personal computer, an e-mail account, and hosting for the individual's web page on the ISP's Internet server. The ISP also takes complete control of the user's existence in cyberspace as soon as she logs on.

If the ISP chooses to do nothing, the user can employ whatever software she desires to experience cyberspace as she sees fit. She can view movie trailers, read about history, send e-mail, or "chat" with her friends. However, the ISP has the power and authority to alter this experience in whatever way it desires. For example, ISPs sometimes offer their users proprietary content such as news, stock quotes, or games. Like city planners, they can create meeting places, facilitate travel through cyberspace, and control the size of crowds. ${ }^{126}$ ISPs can also keep their users from visiting certain parts of cyberspace, censor what they say and read, review their e-mail, monitor their behavior, and enforce codes of conduct. Moreover, an ISP can enforce its will because it controls the user's ability to enter cyberspace. An ISP can "sentence" users who defy its rules by denying access to certain materials, logging them off for specified amounts of time, deleting files kept on the ISP's server, or even terminating the user's account completely. ${ }^{127}$ Moreover, it can do these things arbitrarily without

125. See LESSIG, supra note 65, at 63-84 (discussing various "cyberspaces" and the characteristics chosen for them by their proprietors).

126. Perhaps the best example of this is America Online, which provides its users with special content, chat rooms, and Internet shortcuts not generally available to other Internet users. See LESSIG, supra note 65, at 66-71.

127. ISP user agreements that address these issues include Earthlink, Inc., Earthlink Internet Service Agreement [hereinafter Earthlink Agreement], available at http://www. earthlink.net/about/policies/dial/index.html (last modified March 7, 2000); NetZero, Inc., NetZero Services and NetZero Site Terms and Conditions [hereinafter NetZero Terms and Conditions], available at http://www.netzero.net/legal/serv_terms.html (last visited Nov. 
providing notice, a hearing, or any other form of due process. ${ }^{128}$ In "real space," the power to behave this way rests with the state. In cyberspace, however, it belongs to the cyberlord. ${ }^{129}$

Almost every cyberlord exercises the same power as ISPs by dictating the experience of those who connect to his computer. In some cases, the appearance of the virtual state is clear because the cyberlord creates a virtual community that comes with a governing "constitution." 130 In other cases, the appearance of state power seems nonexistent because the site

16, 2002); America Online, Inc., America Online Member Agreement, $\$ 7$ [hereinafter AOL Agreement], available at http://legal.web.aol.com/aol/aolpol/memagree.html (last visited Nov. 16, 2002); AT\&T, AT\&T Broadband Web Site Agreement [hereinafter $A T \& T$ Agreement], available at http://www.attbroadband.com/services/other/TermsConditions. html (last visited Nov. 16, 2002). These agreements demonstrate that ISPs have the authority and technical power to perform the actions described. Such authority and power exist even in the absence of user agreements because existing law does not regulate the terms and conditions of Internet service.

128. See Rita Ferrandino, Sweaty Scenes from the Life of an AOL Censor, VILLAGE VOICE, Mar. 27, 2001, available at http://www.villagevoice.com/issues/0112/ ferrandino.php (last visited Nov. 16, 2002) (describing activities of a person who enforced America Online's Terms of Service against the service's users). Some writers advocate the use of this power to have ISPs serve as Internet policemen. See Gibbons, supra note 1, at 523-34 (suggesting cooperation between ISPs for the purpose of enforcing standards of behavior in cyberspace as a desirable form of Internet self-regulation).

129. See LESSIG, supra note 65, at 24-42, 63-80 (describing how those in control of computers connected to the Internet can impose control on other Internet users); Joel R. Reidenberg, Governing Networks and Rulemaking in Cyberspace, 45 EMORY L.J. 911, 919 (1996) ("Networks themselves take on political characteristics as self-governing entities."); Gibbons, supra note 1, at 493 ("Similar to feudal fiefdoms, each region, subregion, college, or corporation is responsible for policing its part of cyberspace."); Paul Schiff Berman, Cyberspace and the State Action Debate: The Cultural Value of Applying Constitutional Norms to "Private" Regulation, 71 U. Colo. L. REV. 1263 (2000) (recognizing the power acquired by private parties on the Internet and analyzing the possibility of applying constitutional norms to regulate them).

130. An example of such a community is Cybertown, a virtual community ostensibly "governed" by a constitution. See Cybertown, Inc., Cybertown Constitution, available at http://www.cybertown.com/info/about/details/constitution.html (last visited Aug. 16, 2002). A famous incident involving a virtual rape in LamdaMOO clearly illustrates the similarity between the problems of governing such a site and the problems of "real space" government. In a nutshell, LamdaMOO is a virtual community in which users create characters who "live" in that space. One of LamdaMOO's inhabitants, a "Mr. Bungle," used his status and power to control certain female characters for the purpose of forcing them to participate in nonconsensual sexual activity. Mr. Bungle's behavior presented the LamdaMOO community and its operators with the problem of figuring out what, if anything, to do about Mr. Bungle's behavior. In the end, Mr. Bungle's character disappeared from the system, permanently banished by those in control. See Julian Dibbell, A Rape in Cyberspace, VILLAGE VoICE, Dec. 21, 1993, available at http://www.levity.com/julian/ bungle_vv.html; LESSIG, supra note 65, at 74-78 (discussing the LamdaMOO incident). 
offers users a limited experience such as pure text or technical connection to the Internet's backbone. However, it is still the cyberlord's choice, and not her inability, to offer the limited experience. The private power to shape and control the user's experience still remains.

The hierarchical organization of domain names and computers gives the Internet a distinctly feudal form of government. Cyberlords exercise the power of states as an incident of private property. Additionally, the continuous granting of cyberfiefs and their subsequent division means that this power resides in the hands of numerous cyberlords. The Internet's government, like that of a feudal society, is highly fragmented.

\section{The Development of Cybermanors}

The modern cyberlord faces management problems similar to those confronted by feudal lords. A cyberlord who wishes to earn a fortune in cyberspace has to acquire a cyberfief, but possession of a cyberfief is not enough to ensure prosperity. Like the feudal lord, the cyberlord needs to attract and hold people to make his cyberfief economically productive. This happens at every level of the Internet's feudal hierarchy. At the top, large cyberlords who provide direct connection to the Internet's backbone look for other cyberlords who can profitably utilize Internet bandwidth. At the bottom, cyberlords try to attract ordinary individuals to do the same, but it is at this level that the cyberlord's business turns to exploitation.

At first blush, one might think that cyberlords could profit only if they somehow get their users to pay for the privilege of communicating with the cyberlord's computer. This sometimes happens. For example, Internet users generally pay ISPs a fee in return for their Internet service. However, the cyberlord that limits herself to the collection of user fees is unlikely to maximize profits. Users in cyberspace are consumers in real space, and each of a cyberlord's users represents an opportunity to sell or advertise something. ISPs and other web site operators must therefore attract and retain as many users as they can while connecting their users' "cyberlives" to profits whenever possible. ${ }^{131}$ A profit maximizing strategy starts with

131. A manual for such a management strategy is provided in the book NET GAN by John Hagel III and Arthur G. Armstrong. The authors, who both work for McKinsey \& Company, Inc., advocate the use of what they term "virtual communities" to gain competitive advantages in Internet commerce. Among other things, they stress the importance of attracting users to the site, tracking their usage patterns, and creating disincentives for switching to rivals. JOHN HAGEL III \& ARTHUR G. ARMSTRONG, NET GAIN: EXPANDING MARKeTS Through VIRTUAL COMMUNITIES 131-49 (1997). See also JoHN HAGEL III \& MARC SINGER, NeT WORTH: SHAPING MARKETS WHEN Customers MAKE THE RUles (1999) (describing the "infomediary" as a model by which a business can profit from collection of customer information on the Internet). 
the realization that users experience cyberspace through their computers, ${ }^{132}$ that the cyberlord controls what the computer displays, and that the users' attention, activities, and personal presence become resources that generate revenue for cyberlords. ${ }^{133}$

The most obvious way to accomplish this is displaying advertisements to the user, which many commercial ISPs and web site operators do. ${ }^{134}$ The value of such behavior should not be underestimated. Some ISPs apparently forego user fees altogether in favor of raising revenue from advertisers willing to pay for the display of their ads on users' screens. ${ }^{135}$ Indeed, an aggressive ISP can constantly bombard its users with ads by displaying them upon login, on e-mail screens and in web browser windows. ${ }^{136}$ At the extreme, a user could not be present in cyberspace without the companionship of advertisements. However, ISPs and other web site operators must always be mindful that the overly intrusive use of advertisements may drive users away to competitors. If too many users leave,

132. This includes the computer's screen, audio speakers, keyboard, and any other input or output device.

133. See Suein L. Hwang, Ad Nauseum: Surfers Have Been Ignoring Online Marketing; So Advertisers are Trying Some Creative New Approaches, Wall StreEt J., Apr. 23, 2001, at R8 (describing the importance of more effective targeting of advertisements to internet users), available at 2001 WL-WSJ 2861169; F. T. McCarthy, We Have LiftOff, ECONOMIST, Feb. 3, 2001, (Business Special) (discussing the monetization of a consumer's attention or "eyeballs"), available at 2001 WL 7317530; Erick Schonfeld, How Much are Your Eyeballs Worth?, FORTUNE, Feb. 21, 2000, at 197 (describing how Internet companies are valued by the number of customers they have), available at $2000 \mathrm{WL}$ 3461698; Kara Swisher, Boom Town: AOL Time Warner's New Message to Subscribers: Crazy for You, W ALl STREET J., May 14, 2001, at B1 (describing the importance of subscriber attention), available at 2000 WL-WSJ 2863296.

134. For example, America Online displays an advertisement to each subscriber immediately after she logs in. The subscriber must then respond whether she is interested in the product before she can access her account. Advertisements continue to appear on practically every screen viewed by the user. Earthlink displays advertisements on web browser pages that ordinarily appear when the customer begins surfing the Internet. Yahoo!, Lycos, and Excite display advertisements on practically every page viewed by their users. See Yahoo!, Inc., Yahoo!, available at http://www.yahoo.com; Lycos, Inc., Lycos Home Page, available at http://www.lycos.com; Excite Network, Inc., My Excite, available at http://www.excite.com.

135. See Schonfeld, supra note 133 (describing how NetZero forgoes subscription fees in return for higher advertisement revenue).

136. For example, America Online users are rarely without the company of advertisements when online, particularly when they are in chatrooms or viewing America Online's proprietary content. See, e.g., America Online, Inc., Welcome to AOL Anywhere, available at http://www.aol.com. See also Schonfeld, supra note 133 (describing NetZero's aggressive use of advertisements). 
the value of the cyberlord's advertisement program will decrease, and profits will decrease.

The savvy cyberlord can increase the revenue raised from advertisements by diligently collecting information about his users. Sometimes this information is voluntarily disclosed in exchange for services. For example, ISPs sometimes offer to track a user's stocks or pay her bills online. This can provide valuable clues about a user's wealth. Additionally, users leave many clues about themselves as they move through cyberspace. Some visit web sites devoted to sports. Others go to virtual bookstores. Still others look for stock tips. Cyberlords who record this information can direct advertisements to targeted audiences. ${ }^{137}$ They can put ads for golf clubs on the screens of sports buffs, links to bookstores on the screens of bookworms, and ads for brokerage services on the screens of investors. The narrow targeting of these ads makes them more valuable to advertisers, so the cyberlord can charge more for their display. ${ }^{138}$ If a cyberlord records what his users buy in cyberspace, he has an even better idea of what could be sold to his users and profit from that information as well. ${ }^{139} \mathrm{~A}$ cyberlord could even charge a merchant a percentage of all sales made to users who are directed to the merchant's web site by the cyberlord. ${ }^{140}$ Even if a cyberlord chooses not to use this information himself, he can still profit by selling it to someone who will. ${ }^{141}$

137. See Hwang, supra note 133 (noting how web sites use tracking technology to improve the value of advertisements on the Internet); Chip Bayers, The Promise of One to One (A Love Story), WIRED, May 1998 (reporting that web sites gather information about Internet users for the purposes of advertising and sales), available at http://www.wired.com/wired/archive/6.05/one_to_one.html; Schonfeld, supra note 133 (stating that NetZero monitors every move of its subscribers on the Internet for the purpose of delivering targeted advertisements).

138. See Schonfeld, supra note 133 (noting that NetZero's superior targeting of advertisements increases its revenues); McCarthy, supra note 133 (reporting that Yahoo! targeted ads by observing user behavior, and that such ads sell for 30-60 times as much as untargeted ads); Paul C. Judge, Will Online Ads Ever Click?, FAST COMPANY, Mar. 1, 2001, at 182 (discussing importance of targeting for advertisements and role played by gathering of information about customers in effective advertising), available at $2001 \mathrm{WL}$ 2074101.

139. See Hagel \& ARMSTRONG, supra note 131, at 131-49 (detailing business strategy for vendors to use Internet sites to increase effectiveness of marketing and sales efforts, particularly through the gathering of information about users).

140. See Swisher, supra note 133 (reporting the statement of Bob Pittman, the then co-chief operating officer of AOL Time Warner, that future revenue will come from subscription fees, add-on products, and the ability to "rent the relationship" to others).

141. See Thomas E. Weber, Network Solutions Sells Marketers its Web Database, WALL ST. J., Feb. 16, 2001, at B1 (reporting that Network Solutions, the unit of VeriSign that operates significant portions of the DNS, is offering its database of individuals and 
Cyberlords can also raise revenue by effectively managing the personal presence that their users establish in cyberspace. Any web site operator can easily give users space on a server for the display of the user's web page. ${ }^{142}$ Users create these pages for a wide range of reasons. Sometimes the reasons seem whimsical, as when individuals display pictures of their pets. ${ }^{143}$ At other times the reasons are quite serious, as when users advertise or operate businesses of their own. ${ }^{144}$ Either way, users put up web pages in hopes of attracting visitors. These visitors represent a second audience to whom ads can be shown. The cyberlord can view the user's web page, determine the audience likely to view the page, and target advertisements to that audience. ${ }^{145}$

Really astute cyberlords, however, can accomplish even more by turning their users' personalities into sources of revenue. Of all the things that attract and hold people in cyberspace, human interaction has proven highly effective. This can hardly be surprising. After all, in real space, people generally form their most powerful and long lasting relationships

business who have registered domain names), available at 2001 WL-WSJ 2854616; Nick Wingfield \& Glenn R. Simpson, With so Much Subscriber Data, AOL Walks a Cautious Line on Privacy, WALL ST. J., Mar. 15, 2000, at Bl (reporting that AOL possesses a large amount of data that would generate huge revenue if sold), available at 2000 WL-WSJ 3021761. See also Chris Gaither, Microsoft Poised to Lead .Net Shift, Boston GLOBE, July 29, 2002, at $\mathrm{Cl}$ (describing how Microsoft plans to exploit new markets for Web services, particularly the hosting of software on servers, "to allow a much richer exchange of information between vast repositories of corporate or personal information"), available at $2002 \mathrm{WL} 4140792$.

142. Practically all commercial ISPs offer this service to their subscribers. Additionally, a number of web site operators offer free web page hosting on the Internet. See Yahoo!, Inc., Yahoo! GeoCities, available at http://geocities.yahoo.com/home (offering web page hosting); Lycos, Inc., Tripod, available at http://www.tripod.lycos.com (same).

143. See, e.g., Orchid Fung, Welcome to the World Wide Web's First Golden Retriever WebRing!, available at http://www.geocities.com/Heartland/1763/goldring.html (last updated Feb. 10, 2002) (connecting multiple sites devoted to golden retriever dogs).

144. See e.g., Lycos, Inc., Tripod Small Business, available at http://www.tripod. lycos.com/smallbiz/index.html (last visited Nov. 16, 2002) (offering information and software tools for users to create small Internet businesses).

145. See, e.g., Black Stone Productions, About Black Stone Equine, available at http://black_stone_equine.tripod.com (last updated Nov. 13, 2002) (business web page with banner advertisements placed by the host service provider); The Portable Bistro Home Page, available at http://portablebistro.tripod.com (last visited Nov. 16, 2002) (business web page with a "pop up" advertisement from the host service provider).

The practice of placing advertisements on users' web pages is reminiscent of the manorial practice of requiring serfs to till the lord's fields along with their own. See HALL \& ALBION, supra note 82, at 71. The Internet equivalent of a plot of land is a web page. By making his own "plot of land" more attractive and more valuable, the cyberserf makes the cyberlord's web site more valuable too. 
with other people. Thus, a clever cyberlord provides users the opportunity to chat or otherwise interact "real time" with fellow users in the hope that these users will develop cyberspace relationships. Cyberlords who control access to such users can sell that access. Indeed, the value of such access increases with the number of users available and the intensity of the personal relationships formed. An individual who "sees" a dear friend only in cyberspace will pay more to maintain that connection and will spend more time connected to the cyberlord's site. The increased time spent in cyberspace makes the individual more available for exposure to advertisements and other commercial opportunities controlled by the cyberlord. Moreover, the user's increased presence itself attracts more users who in turn increase the value of the access controlled by the cyberlord. ${ }^{146}$

America Online's proprietary chatrooms offer an excellent example of this. These chatrooms, which only AOL subscribers can access, are organized around themes of common interest. Many of these themes are chosen by the subscribers themselves, and many of the chatrooms have "regulars" who routinely spend a number of hours there every day talking to online friends while also gaining exposure to the ads placed in chatroom windows. Some of AOL's subscribers use the service specifically to gain access to these chatrooms and the friends found there. ${ }^{147}$ AOL understands that the value of its "estate" increases as it attracts more subscribers to its chatrooms and has even recruited its users as "volunteers" who build these communities in exchange for various perks that have included reduced-fee access. ${ }^{148}$

The foregoing shows that cyberlords manage their cyberfiefs like feudal manors. Like feudal serfs, "cyberserfs" live "cyberlives" managed by

146. See Carl Shapiro \& Hal R. VARian, Information Rules: A StrategiC GUIDE TO THE NETWORK ECONOMY 174 (1999) ("Whether real or virtual, networks have a fundamental economic characteristic: the value of connecting to a network depends on the number of other people already connected to it."); LARRY DOWNES \& CHUNKA MUI, UNLEASHING THE KILLER APP: DIGITAL STRATEGIES FOR MARKET DOMINANCE 23-28 (1998) (discussing network effects and the rapid increase of a network's value as the number of users increases); John M. Gallaugher \& Yu-Ming Wang, Network Effects and the Impact of Free Goods: An Analysis of the Web Server Market, INT'L J. ELECTRONIC COM., Summer 1999, at 66, 68-69 (reviewing literature about network externalities), available at http://www2.bc.edu/ gallaugh/research/ijec99/ijec99.html.

147. See DownES \& MUI, supra note 146, at 103 (1998) (describing the value of AOL's chatrooms).

148. See Lisa Margonelli, Inside AOL's "Cyber-Sweatshop", WIRED MAG., Oct.

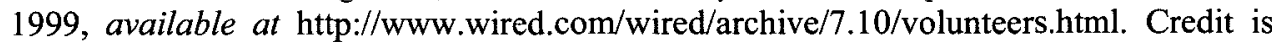
owed to Hector Postigo for drawing this to the author's attention at the Association of Internet Researchers Conference in October 2001. See also Hector Postigo, Final Conference Paper (Oct. 2001) (unpublished manuscript, on file with author). 
their lord for the lord's financial gain. As such, the cyberserf becomes an asset owned by the cyberlord's business. Indeed, as the term "buying eyeballs" suggests, cyberlords sometimes acquire existing cyberfiefs because they deem the cyberserfs valuable. ${ }^{149}$ Even when businesses are not being bought and sold, cyberlords remain keenly aware that their relationships with cyberserfs are valuable assets that can be "rented" to others. ${ }^{150}$ This does not, however, mean that cyberlords routinely abuse their cyberserfs. Just like their medieval counterparts, cyberlords have to limit the exploitation of their cyberserfs because overexploitation will drive cyberserfs to join the cybermanors of his competitors. ${ }^{151}$

\section{THE EFFECT OF THE FEUDAL SOCIETY METAPHOR}

The Feudal Society metaphor challenges the Western Frontier metaphor by diverting attention from romanticized images of the West to the darker ones of feudal Europe. Like America's Western Frontier, medieval Europe had abundant land that governments found difficult to control. However, these conditions did not give rise to a happy European version of the Western Frontier experience. Instead, Europe endured three centuries of feudal rule that declined only as the evolving modern state expanded its regulation of otherwise private feudal arrangements. ${ }^{152}$ The Feudal Society metaphor contradicts the idea that plentiful land and minimal government regulation ensure widespread freedom and prosperity. Indeed, the metaphor implies that such conditions support the fragmentation of political authority and the private exercise of political power. By doing so, the metaphor draws attention to the many instances where, as in medieval Europe, weak states created political vacuums ultimately filled by powerful individuals and clans who governed for private gain. These historical examples make it difficult to accept the Western Frontier metaphor's historical prediction of a glorious future in cyberspace. Rather than presume that things will work out simply because cyberspace resembles

149. See DownES \& MUI, supra note 146, at 102-04 ("The real value in a digital community comes from its participants."). See also supra note 133.

150. See supra note 140 .

151. See supra note 101 and accompanying text (describing possible loss of serfs as a meaningful limitation on the degree of exploitation that feudal lords could practice). See also HAGEL \& ARMSTRONG, supra note 131, at 146-49 (making the imposition of switching costs that make it hard for users to leave a particular Internet community a key component of Internet business strategy).

152. See STRAYER, supra note 82, at 67 (associating the end of feudalism with the rise of the sovereign state); COQUILLETTE, supra note 82, at 107-13, 565-69 (describing the role of the statutes Quia Emptores and De Donis in the decline of feudalism, and discussing the change from feudal society to liberal society). 
the romanticized Western Frontier, society must choose the kind of cyberspace that it will have. ${ }^{153}$

Admittedly, one basis for rejecting this idea is that the institutions and practices emerging in cyberspace do not perfectly mirror those of feudal Europe. Armed retainers do not exist in cyberspace, ${ }^{154}$ and cyberserfs do not face the same degree of subordination that medieval serfs endured. ${ }^{155}$

153. The disintegration of political order and the rise of private warlords in Afghanistan and Somalia offer grim reminders of what can happen, even in the 21 st century, when a country has abundant land and minimal government. The transformation of 20 th century countries into 21 st century quasi-feudal territories is related to Roberto Unger's observation that societies continually cycle through periods characterized by social custom, positive rules built on custom, the rule of law (i.e. liberal society), and the decline of law (postliberal society). See ROBERTO M. UNGER, LAW IN MODERN SOCIETY: TOWARD A CRITICISM OF SOCIAL THEORY 238-42 (1976). Daniel Coquillette has taken Unger's ideas about cycling and inserted new terminology, thereby suggesting that societies naturally start with a tribal phase in which local custom prevails, then experience feudalism, develop into liberal states, and finally pass through a postliberal phase in which the rule of law fails. Societies in the postliberal phase eventually return to the tribal phase. See COQUILLETTE, supra note 82, at 565. Ideas like this predict the development of phenomena like cyberspace which weaken the state and its rule of law, leading society back to the tribal phase and once again to feudalism. Of course, it remains to be seen whether cyberspace will actually have this effect. However, the possibility of this seems undeniable. If society deems such a path undesirable, it should consider what steps might be taken now to prevent the predicted demise of liberal society.

154. See STRAYER, supra note 82, at 13 (including armed retainers in definition of feudalism); BLOCH, supra note 82 , at 446 (noting the importance of the military in medieval feudalism). One could think of computer security experts as the Internet equivalent of armed retainers. Internet computer operators live with the constant threat of attacks in the form of viruses, worms, and hacks. Computer security experts write anti-virus programs and construct security systems to defend against these attacks, thereby providing services similar to those provided by feudal armed retainers. However, one should also keep in mind that computer security experts do not swear oaths of loyalty to their employers, so the similarity between modern computer security experts and feudal armed retainers is limited.

155. If one strictly limits the comparison to humans who lived as medieval serfs and the humans who become cyberserfs when they log on to the Internet, this statement is true. However, if a person's cyberspace identity has significance independent of any real space person, as suggested by at least one academic, things look different. See Curtis E. A. Karnow, The Encrypted Self: Fleshing Out the Rights of Electronic Personalities, 13 J. MARShall J. COMPUTER \& INFO. L. 1 (1994). Although every cyberspace identity corresponds to a real space person, there are clearly cyberspace identities with no true real space counterpart because people deliberately assume cyberspace identities that are different from those they have in real space. For example, a person may choose to conceal his or her racial identity or gender. Others might reveal personal struggles with substance abuse or family history only in cyberspace because conversations about those issues cannot easily be linked to a real space life. Still others could fabricate entire personas for purposes of a cyberspace life. See Kang, supra note 65, at 1133-34 (recounting an Asian American man's experiences in cyberspace while under the identity 
However, metaphors may provide insight without perfectly describing the things they illuminate. The Western Frontier metaphor offers insight despite its imperfections. The Feudal Society metaphor does likewise by suggesting a very complicated future for the denizens of a cyberspace dominated by unregulated private ordering. Instead of being free and prosperous, these denizens may find themselves controlled and exploited by superiors in a technological hierarchy of power. In order to prevent this, a society should use the Feudal Society metaphor to find examples of emerging feudal practices, and then focus on these problems and how they can be blunted by the application of law.

\section{A. User Exit and Emerging Feudal Practices}

ISP regulation is one example of how the Feudal Society metaphor might affect the application of law to cyberspace. As noted earlier, supporters of minimal Internet regulation often argue that easy exit in cyberspace gives users the power to avoid ISPs and others who treat them poorly. Cyberlords will ultimately fail in their efforts to exploit because exploited cyberserfs will surely leave. Accordingly, there is no good reason to regulate the operations of ISPs. ${ }^{156}$

The Feudal Society metaphor implies that this conclusion is a bit premature. While genuinely free exit would help control exploitative behavior in cyberspace, the Feudal Society metaphor suggests that cyberlords will try to defeat free exit by creating "sticky" relationships that increase the value of their cybermanors. ${ }^{157}$ Cyberlords who exploit barriers to exit will not only profit from the increased number of cyberserfs that they control, but also from the willingness of those cyberserfs to tolerate more onerous conditions than those tolerated by cyberserfs who are truly free to leave. Indeed, as noted below, the decision to leave an ISP sometimes has sufficient costs to undercut an "exit cures everything" strategy to Internet pol-

American man's experiences in cyberspace while under the identity of an African American man).

The existence of separate cyberspace identities means that those virtual people exist totally within the confines of cyberspace. As such, the exploitation they face in cyberspace is not necessarily offset by the mitigating circumstances of real space. When an ISP deletes certain cyberspace identities, no real space counterpart carries on. In cases like these, an ISP acquires a great deal of power over a cyberspace person because the ISP has the power and authority to terminate the user's account and by extension the cyberspace person's very existence. This degree of power seems relatively comparable to the power of feudal lords over serfs.

156. See supra notes 63-64 and accompanying text.

157. See supra Part IV.C.2. 
icy. It therefore makes sense to consider passing laws that dismantle existing barriers to exit and prevent future creation of such barriers.

Consider first the exit options available to a casual Internet user, the kind who occasionally visits cyberspace to read about bicycle racing in Europe and get e-mail from one or two friends. Such a person would probably consider most ISPs fungible because they all would give her an e-mail account and allow her to read about bicycle racing. Leaving one ISP for another would therefore cost her very little, and she would theoretically be very prone to switching as long as the new ISP treats her better.

In practice, however, an ordinary Internet user cannot easily find a new ISP who offers a better deal. Despite the existence of many ISPs, ${ }^{158}$ industry consolidation means that most users will encounter only a small number of ISPs who offer relatively similar packages. ${ }^{159}$ Moreover, users considering a switch will have to scrutinize lengthy user and privacy policies that they will find difficult to understand because their casual use of the Internet makes them unfamiliar with the nuances of Internet service. ${ }^{160}$ ISPs can add to these problems by imposing requirements for termination of an account. For example, ISPs sometimes refuse to accept e-mail terminations of an account. Instead, users must cancel by U.S. mail, registered mail, or telephone. ${ }^{161}$ ISPs also use customer service representatives to talk canceling users out of their decisions. ${ }^{162}$ These impediments may not seem terribly burdensome, but they are enough to exploit human inertia and indifference. As noted earlier, a casual user of the Internet has little at stake in her choice of ISPs. She is willing to move for a better deal, but her indifference makes it unlikely that another ISP can offer anything of great

158. Gregg Keizer, The Best and Worst ISPs, PC WoRLD, Nov. 1, 2000, at 148 (reporting that 7,400 ISPs exist), available at $2000 \mathrm{WL} 9395596$.

159. See Kathryn Balint, The Ins and Outs of Choosing a Service Provider, SAN DiEgo UNION-TRIB., June 13, 2000, at 6 (reporting that six ISPs-America Online, Microsoft Network, EarthLink, CompuServe, AT\&T WorldNet, and NetZero-account for nearly $75 \%$ of the nation's total online audience), available at 2000 WL 13970183.

160. For example, the NetZero user agreement and privacy policy occupy twelve single spaced pages, enough to deter many laypersons from thorough review.

161. See AOL Agreement, supra note 127, at $\S 7$ (stating that cancellation must take place by telephone, fax or U.S. mail); Earthlink Agreement, supra note 127, at $\S 10$ (same).

162. See Balint, supra note 159 (reporting that America Online customers find it difficult to terminate their subscriptions in part because of the sales pitch given upon attempts to cancel); Federal Trade Commission, Juno Online Services Settles FTC Charges of Internet Service Advertisements (May 15, 2001) (FTC News Release) (reporting consent agreement between FTC and Juno Online Services, Inc. concerning practices "that made it unreasonably difficult for some customers to cancel" service), 2001 WL 513200. 
value. Consequently, small inconveniences and costs can slow the exit rate of casual users.

Barriers that affect whether serious Internet users will change ISPs are different than the ones described above. Not surprisingly, serious users are a cyberlord's most valuable cyberserfs. They see more ads and they are more likely to buy lots of merchandise. They spend more time creating attractive web pages that bring more users to the ISP's site. ISPs therefore have particular reason to hold on to serious users. However, as will be shown here, the circumstances that deter casual Internet users from switching have less effect on serious Internet users. Nevertheless, the feudal organization of the Internet helps ISPs hold on to these valuable cyberserfs.

Like casual users, serious Internet users are willing to switch ISPs if they can get a better deal from someone else. However, serious users approach their decisions differently because they are more likely to have made a commitment to a particular cyberspace identity. For example, serious Internet users often have a web page on their ISP's server and many friends or business contacts who reach them by e-mail.

In one sense, it is easier for a serious Internet user to switch ISPs. His familiarity with the Internet increases the likelihood that he will receive accurate information about rival ISPs and understand the nuances of various user agreements. His intensity of Internet use means that he has more to gain or lose from a better deal, and this will make him more willing to fight his way through the obstacles that deter casual Internet users.

In another sense, however, it is much more difficult for a serious Internet user to switch ISPs and change communities in cyberspace. For example, a person who has developed a cyberspace identity loses it when he changes ISPs. E-mail addresses generally incorporate the ISP's domain name, as do the URLs of web pages. ${ }^{163}$ These domain names belong to ISPs because ISPs have claimed ownership through the relevant TLD registry. Users who switch ISPs can therefore no longer use the names by which they are known and found in cyberspace. ${ }^{164}$

For casual users, loss of an e-mail address is no big deal because it is easy to give a new e-mail address to a short list of correspondents. By con-

163. The web page's URL usually contains the ISP's domain name (i.e. www2.bc.edu/ yen), and an e-mail address ends with the ISP's domain (i.e. yen@bc.edu). See GraLla, supra note 15, at 16, 144-45. 160-71.

164. See LESSIG, supra note 65 , at 202 (describing how users have difficulty changing communities in cyberspace). An example of this if offered by an AOL volunteer who is reluctant to be publicly identified when speaking about AOL for fear of losing her AOL account and online identity. Margonelli, supra note 148. 
trast, someone with hundreds or thousands of e-mail correspondents could easily lose touch with a number of them. ${ }^{165}$ Most heavy e-mail users do not have the e-mail addresses of everyone who sends e-mail to them, so at the very least a certain percentage of those correspondents will find that the user has "disappeared." 166 Similar problems may arise when a web page is moved from one server to another. This does not mean that switching ISPs is an insurmountable problem for serious Internet users. Serious users can and do switch ISPs. However, it is clear that the decision to switch ISPs has costs for serious users, and these costs seem large enough to impede their exit rate.

The Feudal Society metaphor shows that ISPs will try to create, maintain, and exploit barriers to user exit because those barriers increase the value of cyberfiefs. ${ }^{167}$ If free user exit is to play a significant role in preventing the exploitation of individuals in cyberspace, it seems worthwhile to seriously consider using law to lower barriers to user exit. If an ISP's ownership of domain names, URLs, and e-mail addresses raise the costs of switching, the state could lower the relevant costs by requiring ISPs to automatically forward e-mails and redirect users looking for relocated web pages. It might even be appropriate to give users limited licenses to use domain names, URLs, and e-mail addresses after leaving an ISP. Additionally, if casual users find it difficult to determine whether their ISPs are offering good deals, a state could force ISPs to disclose basic information about service to users in standard formats that make comparison shopping easy. ${ }^{168}$

165. See Lemley, supra note 73 , at $1269 \mathrm{n} .55$ (noting that distribution of an e-mail address to numerous correspondents makes it harder to leave an ISP).

166. See David Coursey, ISP Switch? Learn My Secrets for Holding on to Your Email, ZDNet AnchorDesk (describing loss of e-mail addresses as a problem when switching ISPs and partial solutions for handling the problem), available at http://www. zdnet.com/anchordesk/stories/story/0,10738,2767997,00.html (June 4, 2001).

167. Proponents of a laissez-faire approach may argue that sophisticated Internet users can easily avoid these problems by registering and administering their own Internet domains. It is true that users who register their own domain names can establish identities not owned by their ISPs. However, there are still problems with this as a panacea to the problem of cyberserfhood. First, it is unlikely that casual users will know enough about the Internet to register their own domains and configure the necessary technology. Second, by the time they become the serious users who are able to do this, they then must face the loss of their ISP-owned name. Again, the point is not that exit is impossible, but that significant obstacles to exit exist.

168. The federal government already imposes similar requirements on consumer mortgage lenders. 15 U.S.C. $\S \S 1601-1693$ (2000) (regulating disclosure of finance charges and annual percentage rate); 12 U.S.C. $\S \S 2601-2617$ (2000) (regulating disclo- 


\section{B. Contracts of Adhesion and Emerging Feudal Practices}

Enforcement of adhesion contracts between cyberlords and cyberserfs is another example of how the Feudal Society metaphor might affect the application of law to cyberspace. Consider the standard agreement between an ISP and its subscriber. ISPs generally set the terms of these agreements on a "take it or leave it" basis, and they expressly permit ISPs to collect information about their users, enforce codes of conduct, change the agreement unilaterally, and terminate a user's account without notice. ${ }^{169}$ When one applies the Feudal Society metaphor, these agreements bear some resemblance to feudal pledges of loyalty and fealty, and they signal the cyberserf's acceptance of a cyberlife in service to the cyberlord. ${ }^{170}$

sures about closing costs). Such disclosures help consumers choose among deals that might otherwise be impossible to compare.

169. See Earthlink Agreement, supra note 127 (containing terms granting the ISP broad rights to monitor and control the subscriber's Internet use); NetZero Terms and Conditions, supra note 127 (same); AOL Agreement, supra note 127 (same); AT\&T Agreement, supra note 127 (same).

170. For example, the America Online Member Agreement and AT\&T Broadband Agreement grant broad licenses to the ISP concerning the use of the subscriber's intellectual property. See AOL Agreement, supra note $127, \S 3$ (containing provision that the user grants AOL the "complete right to use, reproduce, modify, distribute, etc. the content in any form, anywhere."); $A T \& T$ Agreement, supra note $127, \S 2$ ("You agree to grant to AT\&T Broadband a nonexclusive, royalty-free, worldwide, perpetual license, with the right to sublicense, to reproduce, distribute, transmit, create derivative works of, publicly display and publicly perform any materials and other information (including, without limitation, ideas contained therein for new or improved products and services) you submit to public areas of the Service (such as bulletin boards, forums and newsgroups) by all means and in any media now known or hereafter developed."). The NetZero subscriber agreement states that NetZero will collect information about where users go and "may" make that information available to third parties. See NetZero Terms and Conditions, supra note $127, \S 1.0$. A "cookie" is a text file that:

allows Web sites to recognize particular users on future visits, enabling Web sites to provide personalized information or to automate the log in process. On some sites, cookies are essential for navigation. Cookies were originally designed to be contained within a specific site; however, when set by an ad server . . . they can be read by any server in the ad company's domain, no matter what URL the browser is displaying or what site is on the screen. Thus, one company can collect information on a particular individual's activities on any number of sites.

Richard Raysman \& Peter Brown, Protecting Consumer Privacy: Are You Prepared?, N.Y.L.J., Apr. 11, 2000, at 3, reprinted in Jane Kaufman Winn \& James R. Wrathall, Who Owns the Customer? The Emerging Law of Commercial Transactions in Electronic Customer Data, 56 Bus. LAw. 213, 223 (2000). See also Jerry Kang, Information Privacy in Cyberspace Transactions, 50 STAN. L. REV. 1193, 1227-29 (1998) (describing use of cookies); Schwartz, supra note 65, at 1624-26 (same). 
To what extent should contracts like these be enforced? As adhesion contracts, they vary from the ideals of contract law. The parties do not negotiate over the contract's terms. Additionally, the contracts are often presented at a time when the offeree is unlikely to review the terms of the deal. Finally, adhesion contracts are often lengthy documents that ordinary individuals may find difficult to understand. These problems indicate that adhesion contracts rarely embody the genuine assent of the offeree, and the likelihood exists that ISPs use their service agreements to impose conditions that the users neither agree to, know of, nor understand. ${ }^{171}$

Despite these problems, courts generally enforce adhesion contracts in cyberspace. ${ }^{172}$ However, courts leave open the possibility that particular provisions of adhesion contracts will be found unenforceable if those provisions are unconscionable or violate public policy. ${ }^{173}$ Therefore, the vi-

171. See Todd D. Rakoff, Contracts of Adhesion: An Essay in Reconstruction, 96 HARV. L. REV. 1174, 1179 (1983) (defining and analyzing contracts of adhesion); Saul Litvinoff, Consent Revisited: Offer, Acceptance, Option, Right of First Refusal, and Contracts of Adhesion in the Revision of the Louisiana Law of Obligations, 47 LA. L. REV. $699,757-58$ (1987) (describing problems of consent in adhesion contracts).

172. See Rakoff, supra note 171 , at $1191-92$ (discussing general enforceability of adhesion contracts). See also ProCD, Inc. v. Zeidenberg, 86 F.3d 1447 (7th Cir. 1996) (enforcing a so-called "shrinkwrap" license that accompanied a CD-ROM containing a database of telephone numbers); Hill v. Gateway 2000, Inc., 105 F.3d 1147 (7th Cir. 1997) (enforcing a software license that came with a personal computer); In re RealNetworks, Inc., No. 00 C 1366, 2000 U.S. Dist. LEXIS 6584, 2000 WL 631341 (N.D. Ill. May 8, 2000) (holding a "clickwrap" agreement valid and enforceable); Hotmail Corp. v. Van\$ Money Pie, Inc., No. C98-20064, 1998 U.S. Dist. LEXIS 10729, at *16-17, 1998 WL 388389 , at $* 6$ (N.D. Cal. Apr. 16, 1998) (concluding that plaintiff had strong likelihood of success with respect to enforcing an online contract of adhesion). A recent case of interest is Specht v. Netscape Communications Corp., 150 F. Supp. 2d 585 (S.D.N.Y. 2001). The Specht court held that the mere act of downloading software over the Internet was not enough to bind users to a license. Id. at 595-96. At the same time, however, the court endorsed the general enforceability of adhesion contracts, including clickwrap agreements. Id. at 592. Specht indicates that ISPs can create enforceable agreements as long as they induce customers to specifically indicate assent to the terms of adhesion contracts. See id. at 595-96. The ease with which most users click "I accept" means that, as a matter of practice, ISPs and other Internet entities should have little trouble binding individuals to adhesion contracts on the Internet. For an interesting and thoughtful analysis of how adhesion contracts affect the use and availability of information on the Internet, see Michael J. Madison, Legal-Ware: Contract and Copyright in the Digital Age, 67 ForDHAM L. REV. 1025 (1998).

173. See ProCD, 86 F.3d at 1449 ("Shrinkwrap licenses are enforceable unless their terms are objectionable on grounds applicable to contracts in general (for example, if they violate a rule of positive law, or if they are unconscionable)."); In re RealNetworks, 2000 U.S. Dist. LEXIS 6584, at 14-21 (considering, but rejecting, claim of unconscionability). 
ability of feudal practices in cyberspace depends in part on how courts perceive various contractual provisions.

The existing general enforcement of adhesion contracts in cyberspace is consistent with the Western Frontier metaphor's dominance. That metaphor constructs cyberspace as a place where exploitation of ordinary individuals is very unlikely - certainly less likely than in real space. Due to the improbability of exploitation, courts correctly refuse to invalidate or curtail the provisions of adhesion contracts between cyberlords and cyberserfs.

By contrast, the Feudal Society metaphor suggests that cyberspace does not automatically protect ordinary individuals from exploitation. Indeed, it suggests that such exploitation is spreading in cyberspace and that computer technology facilitates exploitative feudal practices. If society wants to prevent this, a sensible response would be to construct or interpret contract law to prohibit or regulate contractual provisions that support feudalism in cyberspace. This does not necessarily mean that unilateral changes to agreements, limited remedies, choice of forum clauses, unlimited licenses of intellectual property from cyberserf to cyberlord, mandatory consent to data collection, or low limitations of liability could never be part of a contract between a cyberlord and cyberserf. ${ }^{174}$ The Feudal Society metaphor merely tells us that the present routine acceptance of such provisions is probably unwarranted. In order to curb potentially exploitative methods, courts should therefore seriously consider scrutinizing the provisions of adhesion contracts in cyberspace more closely than they have in the past.

\section{Intellectual Property and Emerging Feudal Practices}

A third example of the Feudal Society metaphor's insight is its illumination of how intellectual property operates in cyberspace. Intellectual property is typically understood as law that encourages innovative and creative activity by reducing the likelihood of free riding. ${ }^{175}$ However, the

174. For examples of such provisions, see $A O L$ Agreement, supra note 127 (unilateral changes in terms of service, limited remedies, choice of forum clauses, and broad intellectual property licenses); AT\&T Agreement, supra note 127 (unilateral changes in terms of service, choice of forum clauses, and broad intellectual property licenses); and NetZero Terms and Conditions, supra note 127 (collection of personal information, limits on liability).

175. See U.S. ConST. art. $1, \S 8, \mathrm{cl} .8$. (Congress shall have power "[t]o promote the Progress of Science and useful Arts, by securing for limited Times to Authors and Inventors the exclusive Rights to their respective Writings and Discoveries . . .."). Also see Sony Corp. of Am. v. Universal City Studios, Inc., 464 U.S. 417, 429 (1984) in which the Court states that 
Feudal Society metaphor suggests that intellectual property also plays a role in the privatization of state functions and the ability of cyberlords to control cyberserfs.

\section{The DMCA and Creation of Private Judiciaries}

Title II of the Digital Millennium Copyright Act ("DMCA") ${ }^{176}$ provides an example of how intellectual property law can be constructed to encourage the development of private judiciaries. The DMCA addressed the question of whether ISPs could be held liable for copyright infringement committed by their users. ${ }^{177}$ However, rather than clarifying the substantive law about such liability, the DMCA permits ISPs to avoid such liability as long as they assume the role of private courts that hear complaints of copyright infringement.

Among other things, ISPs who want to take advantage of the DMCA's safe harbor provisions must designate an agent to receive written complaints of copyright infringement committed by the ISPs users. ${ }^{178}$ These complaints must follow a specified format. Once ISPs receive such formal complaints, they must "expeditiously" disable access to the alleged infringing material and notify the affected user of the complaint and the action taken. ${ }^{179}$ The user then has the opportunity to respond with a denial of the initial allegation that requires the ISP to restore access to the material in question. ${ }^{180}$ However, if the complainant continues to press the action by filing an action in court, the ISP must again disable access to the in-

[t]he monopoly privileges that Congress may authorize are neither unlimited nor primarily designed to provide a special private benefit. Rather, the limited grant is a means by which an important public purpose may be achieved. It is intended to motivate the creative activity of authors and inventors by the provision of a special reward, and to allow the public access to the products of their genius after the limited period of exclusive control has expired.

The Court in Mazer v. Stein, 347 U.S. 201, 219 (1954) stated:

[t]he economic philosophy behind the clause empowering Congress to grant patents and copyrights is the conviction that encouragement of individual effort by personal gain is the best way to advance public welfare through the talents of authors and inventors in 'Science and useful Arts.'

176. 17 U.S.C. $\$ 512$ (2002).

177. An extensive analysis of the relevant issues can be found in Alfred C. Yen, Internet Service Provider Liability for Subscriber Copyright Infringement, Enterprise Liability, and the First Amendment, 88 GEO. L. J. 1833 (2000).

178. 17 U.S.C. $\S 512(c)(2)(1998)$.

179. 17 U.S.C. $\S 512(\mathrm{c})(1)(\mathrm{C}),(\mathrm{g})(2)(\mathrm{A})$.

180. 17 U.S.C. $\S 512(\mathrm{~g})(2)(\mathrm{C}),(3)(\mathrm{C})$. 
fringing material. ${ }^{181}$ The DMCA generally protects ISPs who follow these procedures from liability for their users' infringements. ${ }^{182}$

The DMCA encourages ISPs to behave like courts of first resort in cases of copyright infringement on the Internet. Copyright plaintiffs file a statutorily prescribed complaint. ${ }^{183}$ ISPs then investigate the allegation and, if the allegations seem plausible, essentially grant the plaintiff a temporary restraining order against the defendant by disabling access to the alleged infringing material. ${ }^{184}$ Such action is probably enough to resolve many cases without resort to the public judicial system because defendants will often not contest the allegations made against them. In those cases where defendants choose to fight, the plaintiff can still enforce its virtual temporary restraining order by filing the appropriate action in a formal court of law. ${ }^{185}$

Although the above-described procedures might seem sensible, they are actually quite problematic. People who litigate disputes in public courts expect judges to have no self-interest in the outcome. Indeed, judges ordinarily recuse themselves in cases where their personal finances may be at stake. By contrast, ISPs have an obvious financial interest in the cases they are asked to hear because the DMCA prohibits liability against ISPs who remove material from the Internet in response to complaints from copyright holders. ${ }^{186}$ This interest encourages ISPs to resolve initial doubts in favor of plaintiffs to the detriment of defendants. Additionally, these procedures benefit copyright plaintiffs since they can get more from private courts than they could get from public courts. The ease with which plaintiffs obtain virtual temporary restraining orders from ISPs stands in sharp contrast to what plaintiffs must do for real ones from public courts, where due process would otherwise require a hearing and posting of a bond. $^{187}$

The private justice meted out by ISPs under the DMCA has the very shortcoming associated with feudal justice. Feudal lords or henchmen sitting in manorial courts would surely keep the lords' interest in mind when

181. 17 U.S.C. $\S 512(\mathrm{~g})(2)(\mathrm{C})$.

182. 17 U.S.C. $\S 512$ (c); Yen, supra note 177, at 1881-85 (describing requirements of the DMCA).

183. 17 U.S.C. $\S 512(\mathrm{c})(3)$.

184. 17 U.S.C. $\$ 512(\mathrm{c})(1)(\mathrm{C})$.

185. 17 U.S.C. $\$ 512(\mathrm{~g})(2)(\mathrm{C})$.

186. 17 U.S.C. $\$ 512$ (c).

187. See Yen, supra note 177, at 1885-89 (analyzing the safe harbor provisions of the DMCA). 
deciding cases, ${ }^{188}$ and so it is with ISPs under the DMCA. By contrast, the end of feudalism is associated with the rise of the liberal state and the rule of law. ${ }^{189}$ Modern liberal states expect formal disputes to be settled by judges who refer to legal rules without regard to their personal interest. Accordingly, the private justice mechanism created by the DMCA represents a step away from the liberal state back towards a feudal system of justice. It may therefore be desirable to curtail or eliminate intellectual property laws like the DMCA that encourage or require self-interested judicial behavior by private parties.

\section{Intellectual Property Cases and the Control of Cyberserfs}

The connection between intellectual property and the fight over cyberserfs can be seen in the three highly publicized cases of $A \& M$ Records, Inc. v. Napster, Inc. ${ }^{190}$ Amazon.com, Inc. v. Barnesandnoble.com, Inc., ${ }^{191}$ and eBay, Inc. v. Bidder's Edge, Inc. ${ }^{192}$ In Napster, the defendant Napster, Inc. operated a directory service that facilitated the swapping of MP3 files over the Internet. ${ }^{193}$ Napster users would use the Internet to log on to the Napster service and send a search request to Napster for a particular song or artist. Napster would respond with a list of all logged on Napster users who had the relevant files available for downloading. The user could then download the desired music directly from another user. ${ }^{194}$ Napster proved extremely popular, attracting some 36 million users. ${ }^{195}$ Many of these users committed copyright infringement. ${ }^{196}$ However, a consortium of record companies and music publishers chose not to enforce their rights directly against Napster's users. Instead, they sued Napster for vicarious and contributory copyright infringement, alleging that Napster itself was liable for the misbehavior of its users. ${ }^{197}$ The plaintiffs successfully obtained a preliminary injunction against Napster. ${ }^{98}$ After settlement negotiations with the consortium collapsed, Napster sought to show the recording industry

188. See BlOCH, supra note 82 , at 359-60 (describing desire of lords to sit in judgment in part because it was in the lords' financial interest).

189. COQUILLETTE, supra note 82, at 565.

190. 239 F.3d 1004 (9th Cir. 2001).

191. 239 F.3d 1343 (Fed. Cir. 2001).

192. 100 F. Supp. 2d 1058 (N.D. Cal. 2000).

193. Napster, 239 F.3d at 1011.

194. Id. at 1011-13.

195. See Andrew Morse, Judging Napster, INDUSTRY STANDARD, Oct. 27, 2000 , available at $\mathrm{http}: / / \mathrm{www}$. thestandard.com/article/0,1902,19760,00.html.

196. Napster, 239 F.3d at 1013-14.

197. Id. at 1011.

198. Id. at 1027. 
had engaged in copyright misuse. ${ }^{199}$ Napster filed for bankruptcy in June $2002{ }^{200}$ The case is ongoing.

The Amazon.com case involved a dispute over Amazon's patented "single-action" method for selling merchandise over the Internet. ${ }^{201}$ It allowed customers to buy items with a single mouse-click and made use of the Amazon.com web page more convenient than competitors' pages that required multiple clicks for purchases. ${ }^{202}$ The defendant Barnesandnoble.com adopted a similar method for taking orders without Amazon's consent, and Amazon sued for patent infringement. ${ }^{203}$ Amazon obtained a preliminary injunction, ${ }^{204}$ but the Federal Circuit vacated the district court's order. ${ }^{205}$ The case settled in March 2002. ${ }^{206}$

In $e B a y$, the plaintiff eBay operated a popular web site that offered auctions for various items. ${ }^{207}$ The defendant Bidder's Edge, Inc. ran a web site that allowed users to view prices on multiple auction sites, including eBay's, simultaneously. ${ }^{208}$ This made it easier for users to comparison shop because it obviated the need to visit multiple sites. ${ }^{209}$ Bidder's Edge obtained its information about eBay by using software robots that sent repeated requests for items and prices to eBay. ${ }^{210}$ eBay objected to the defendant's practice, and sued, alleging causes of action in trespass, false advertising, trademark dilution, computer fraud and abuse, interference with prospective economic advantage, and unjust enrichment. ${ }^{211}$ eBay succeeded in obtaining a preliminary injunction on a trespass claim against Bidder's Edge, ${ }^{212}$ but the case has since been settled. ${ }^{213}$

199. Dawn C. Chmielewski, Judge Will Let Napster Probe Labels' Conduct, SAN JOSE MERCURY-NEWS, Feb. 23, 2002, at 3, available at 2002 WL 14897580.

200. What's News, Business and Finance, WALL ST. J., June 4, 2002, at A1, available at 2002 WL-WSJ 3396602.

201. Amazon.com, Inc. v. Barnesandnoble.com, Inc., 239 F.3d 1343, 1347 (Fed. Cir. 2001).

202. Id. at $1347-50$.

203. Amazon.com, Inc. v. Bamesandnoble.com, Inc., 73 F. Supp. 2d 1228, 1231

(W.D. Wash. 1999), vacated by 239 F.3d 1343 (Fed. Cir. 2001).

204. Id. at 1249.

205. Amazon.com, 239 F.3d at 1366.

206. Amazon Settles Suit Against Online Rival Over Buying Shortcut, WALl ST. J., Mar. 8, 2002, B5, available at 2002 WL-WSJ 3388159.

207. eBay, Inc. v. Bidder's Edge, Inc., 100 F. Supp. 2d 1058, 1060 (N.D. Cal. 2000).

208. Id. at 1061-62.

209. Id. at 1062 .

210. Id. at 1060-63.

211. Id. at 1063.

212. Id. at 1073. 
Ordinarily, these cases would be viewed as three legally distinct intellectual property disputes whose parties happen to include Internet businesses. Intellectual property laws, such as copyright and patent laws, exist to provide incentives for the creation of socially valuable works and inventions. ${ }^{214}$ Given the philosophy behind the granting of intellectual property rights, resolution of these cases therefore involves consideration of how property rights affect incentives for the creation of content distributed over the Internet, Internet business methods, and the maintenance of web sites. A court might find for the recording industry in Napster because doing so gives copyright holders incentives to create music and distribute it online. A court might hold Amazon's patent valid because it believes that such innovation would not occur without patent protection. eBay may have ultimately won because a court believed that such businesses could not be profitably maintained without a prohibition against the commercial use of information by others.

By contrast, the Feudal Society metaphor ties these cases together by drawing our attention to the common struggle for the control of cyberserfs. By using what the plaintiff claimed as intellectual property, each defendant was luring users away. The music industry wanted Napster users to visit the industry's web sites, Barnesandnoble.com shoppers were ones that Amazon.com thought it had "captured" by pioneering Internet book selling, and eBay wanted to keep Bidder's Edge users at the eBay site. Each plaintiff sued because it feared that the loss of cyberserfs would destroy its cybermanor. These observations show that a wide variety of intellectual property disputes may not really be about incentives for invention or creation, but about the allocation of power to control people who use the Internet. If that is so, the stakes in such cases have changed and we may need to rethink the desirability of strong intellectual property rights in cyberspace. It is one thing to decide cases about the control of economic rights related to innovation. It seems to be something quite different to decide cases about the right to control people in their travels through cyberspace. Perhaps some otherwise plausible claims of intellectual property should be limited in order to control undesirable, quasi-feudal practices.

213. See Greg Wiles, eBay, Bidder's Edge Settle Suit on Web Trespassing, Copyright, BLOOMBERG NEWS, Mar. 1, 2001, available at LEXIS, Bloomberg - All Bloomberg News.

214. See supra note 175. 


\section{CONCLUSION}

This Article has shown the value of consciously developing alternate, complementary metaphors for cyberspace. The basic insight here is easily understood. If single metaphors necessarily miss valuable insights, an effective way to suggest the missing insights is the deployment of multiple metaphors with complementary insights.

For example, the romanticized Western Frontier represents an ideology that emphasizes individual autonomy, free markets and a weak state. The Western Frontier metaphor has a tendency to discount things that might justify relatively strong regulation of cyberspace. Accordingly, a person constructing a complementary metaphor to the Western Frontier metaphor should recognize this oversight and construct a metaphor whose foundation supports a stronger state. Deployment of the complementary metaphor permits the observer to affirm or dispute observations that emerge from the first metaphor. As this Article has shown, the Feudal Society metaphor does just that.

Finally, it may be wise to take note of the people who originate metaphors and their particular points of view. ${ }^{215}$ For example, the Western Frontier metaphor arose among those who first used the Internet. They came to the Internet voluntarily, and they had a relatively large amount of influence over the Internet's development. It made sense for them to see the Internet as a place of freedom and opportunity. By contrast, those who came later to the Internet do not necessarily share the same perspective. Later Internet users would have less say over the Internet's shape, and it is entirely possible that they would consider Internet use a necessity of modern life and not an excellent technological adventure. They could easily associate the Internet with compulsion instead of freedom. ${ }^{216}$ The Feudal Society metaphor gives this perspective an opportunity to be considered. Abuses ignored by those trained to think of the Internet as the "wild west," can be identified and addressed after adopting this alternate perspective.

The metaphors studied by this Article are just two of the many metaphors that can be applied to the Internet. Together, they show the importance of exercising restraint when characterizing the Internet as a phenomenon destined to bring freedom and prosperity. The Western Frontier metaphor conjures up a glorious tale of progress in cyberspace, but the

215 See Margaret Chon, Internet Law Symposium: Introduction, 20 SEATTLE U. L.R. 613 (1997) (noting how metaphors used by symposium participants were closely related to the participants' attitudes towards government).

216 An example of this might be an employee who does not enjoy using computers, but has been told by his employer to use e-mail and the world wide web as part of his job. 
metaphor's flaws make its historical lessons questionable. By contrast, the Feudal Society metaphor shows that very different historical lessons apply to the Internet, and that an unregulated Internet might damage the freedom and prosperity of ordinary individuals. Society should cast a wary eye on policies supported by the Western Frontier metaphor and study how it can use law to realize the Internet's promise. 
BERKELEY TECHNOLOGY LAW JOURNAL 